\title{
Intergenerational inequalities in mortality-adjusted disposable incomes
}

\author{
Hippolyte d'Albis ${ }^{1, *}$ and Ikpidi Badji ${ }^{2}$
}

\begin{abstract}
This article analyses the development of inequalities between the generations in France using a composite indicator including income and life expectancy. Mortalityadjusted disposable income has greatly increased over the generations. However, a breakdown by sex shows that this increasing trend is attributable to rapid growth in women's income, while men's income has stagnated for all cohorts born since 1946.
\end{abstract}

\section{Introduction}

The economic position of young people is a recurring topic in public debate. It is often said that today's younger cohorts are less well off than their parents were at the same ages. This supposed inequality between the generations is likely to affect the design of policies that involve intergenerational transfers. In previous research for France, we showed that there was no decline in living standards between the generations; and, in particular, that the baby boom generation did not enjoy a more favourable position than the generations that followed them (d'Albis and Badji 2017). The various indicators of living standards we used are, however, only economic indicators. Such indicators are obviously imperfect measures of wellbeing, as they may fail to capture an individual's perception of his or her position. In this article, we continue our analysis of inequalities between the generations in France by adding two specifically demographic dimensions.

The first dimension we include is life expectancy. As it is clear that improvement in this variable is a barometer of progress and a source of well-being (Deaton 2013), it is often included in composite indicators used to measure well-being. However, linking an economic variable to a demographic variable is not a simple process. As Deaton (2013) has pointed out, it would be inappropriate to merely multiply

\footnotetext{
${ }^{1}$ Paris School of Economics and CNRS, France

${ }^{2}$ Economix, Université Paris Nanterre, France

${ }^{*}$ Correspondence to: Hippolyte d'Albis, hdalbis@psemail.eu
} 
annual income by life expectancy. For a given permanent income level, an increase in lifespan may indeed be accompanied by a reduction in consumption per period of time. In the following, we use recent literature (Becker et al. 2005; Fleurbaey and Gaulier 2009; Jones and Klenow 2016; d'Albis and Bonnet 2018) based on agents' preferences to incorporate differences in life expectancy into comparisons of income levels between countries. Following the literature on computing the Value of a Statistical Life, the idea behind our approach is to define how much an individual would be willing to pay in exchange for a higher life expectancy. We could, for example, ask how much income an individual would agree to forego in order to enjoy a life expectancy equal to that of the country with the highest average lifespan (d'Albis and Bonnet 2018). The income net of this willingness to pay for a longer life is referred to as "mortality-adjusted income". In this article, we adapt this procedure in order to examine inequalities between the generations. We determine the willingness to pay for each age and each cohort as a function of the life expectancy at that age for a cohort distant in time. For example, we calculate the reduction in income a young person of the baby boom generation might have agreed to forego in exchange for enjoying the life expectancy of their children.

The second dimension we include is gender. Men and women have widely differing incomes and life expectancies, with men, on average, having higher incomes but shorter lives than women. Including this dimension in comparisons of generations has two advantages. First, since variations by gender change over time, examining these differences is one way to better understand average developments. Second, the intergenerational comparisons made by the ordinary person may be implicitly gendered: i.e. a son may compare himself to his father, while a daughter is likely to compare herself to her mother. Even if such gendered comparisons are not universal, this tendency could help to explain the perceptions expressed in surveys.

We used the seven waves of the main French survey of household living conditions to create pseudo cohorts. Unfortunately, we were unable to analyse real cohorts because the survey is not panel-based. The respondents' total incomes were individualised and adjusted using National Accounts. Our econometric modelling is designed to evaluate the effects of age, cohort, and period on disposable income and mortality-adjusted disposable income. To address the problem of collinearity between the explanatory variables, we have adopted Deaton and Paxson's (1994) strategy.

The results are as follows. With the inclusion of increased life expectancy, the relative situations of generations improved considerably during our period of observation. In particular, all of the cohorts born after 1960 enjoyed a level of mortality-adjusted disposable income that was significantly higher than that of the cohort born in 1946. For example, from the 1946 cohort to the 1966 cohort, income rose $28.6 \%$. However, this increase reflects widely differing trends between the sexes. Women's mortality-adjusted income rose quickly $(+38.8 \%$ from the 1946 to the 1966 cohort, and $+76.6 \%$ from the 1926 to the 1946 cohort), while men's income stagnated starting with the 1946 cohort. These findings clearly indicate that women's income levels have been catching up to those of men. Moreover, these 
results are in line with our previous research that focused on men alone (Lefranc 2018, Alesina et al. 2018). We can also see that mortality-adjusted disposable income generally increased over the course of an average lifetime, rising 53\% from ages 27 to $47,7.3 \%$ from ages 47 to 62 , and $50.1 \%$ from ages 62 to 82 . This means that inequalities between ages did not involve inequalities between generations. As d'Albis and Badji (2017) have suggested, economic growth benefits everyone.

The rest of the paper is organised as follows. Section 2 presents the methods we use to obtain our mortality-adjusted incomes, and our econometric strategy. Section 3 presents our results. Section 4 concludes.

\section{Data, measures, and estimation strategy}

Our indicator combines an economic variable that measures living standards and a demographic indicator that measures longevity. There is no consensus on this choice of economic variable. It is true that in most theoretical economic studies, consumption is used as the main element in an individual's utility function. This variable has, for example, been used by Jones and Klenow (2016) to compare levels of wellbeing between countries, and by d'Albis and Badji (2017) to compare well-being between generations. In this article, however, we use disposable income. Unless one accepts the Keynesian theory of a linear connection between consumption and income, this is not a neutral choice. Consumption is both a more extensive variable because it depends on total income received over a life-cycle, and a more restricted variable because it does not include any bequests transmitted to children. d'Albis and Badji (2017) showed, however, that comparisons between generations do not differ qualitatively depending on which variable is used, with the exception that the improvement in living standards between generations is more marked when consumption is used. We have redone this comparison for the present paper (see Appendix B), and found that this conclusion still holds. But our decision to use the disposable income in the current analysis is largely a pragmatic one: i.e. since we are constructing variables for both sexes, income is the more appropriate choice because it is more individualised in surveys. Consumption is, by contrast, generally recorded for the household as a whole. When consumption is individualised, the tendency is to divide it equally among adults. While this approach can generate accurate results, it masks the important dimension of gender inequality. The reduction in the income gap between the sexes, which has undoubtedly led to improvements in women's well-being, would not be discernible if well-being were measured by average household consumption.

\subsection{Disposable income by age and cohort}

Disposable income is defined as an individual's income after the deduction of taxes and social security contributions. It includes: (i) working income: salaries, 
self-employed income, etc.; (ii) income from household worth: dividends, interest, rent, etc., to which we add the imputed rents; (iii) social security benefits, including pension and unemployment benefits; and (iv) current transfers, particularly insurance indemnities minus premiums and transfers between households.

We first compute disposable income using data from the French Household Expenditure Survey (Budget de famille, referred to hereafter as BdF) waves conducted in 1979, 1984, 1989, 1995, 2000, 2005, and 2010. With more than 10,000 participating households, the aim of these surveys was to reconstitute all household accounts by gathering information on the respondents' income and expenditure levels. It is worth noting that in the $\mathrm{BdF}$, a household refers to any group of people who ordinarily share a dwelling and a budget, and who may or may not be related.

We estimate each household's disposable income by adding up all sources of income and deducting any direct taxes paid (income tax, council tax, property tax). As the BdF surveys conducted between 1979 and 1995 did not provide figures for imputed rents, these figures were estimated using the characteristics of housing; as in d'Albis and Badji (2017). All of the variables are deflated using the consumer price index.

Unlike in d'Albis and Badji (2017), in the current analysis we individualise the disposable income following the recommendations made by the National Transfer Accounts (United Nations 2013). The BdF surveys provide some income data at the household level (such as property income, imputed rents, family benefits, transfers between households, and direct taxes paid), and other income data at the individual level. The household-level data are allocated between the members of the household using a sharing rule. Property income, transfers between households, direct taxes, and family benefits ${ }^{1}$ are allocated equally between the household reference person and his or her spouse. Imputed rents are allocated using the NTA rule.

To enable us to compare data within a consistent time frame, we adjust the survey data to the French System of National Accounts aggregates. This adjustment, which is similar to the adjustment carried out for the National Transfer Accounts (d'Albis et al. 2015; 2017), ensures that the aggregate disposable income of individuals is equal to the National Accounts aggregates. Our sample is restricted to ordinary households residing in Metropolitan France. Finally, the rescaled individual variables are split by sex.

Figure 1 shows the disposable income by age for 16 generations. These generations are established using the seven cross-sectional databases we created from the seven BdF surveys. We first built 79 annual cohorts, defined according to the reference individual's date of birth. The first cohort was born in 1901, while the last cohort was born in 1979. The generations are then defined using the mean of five consecutive cohorts (except for the first generation, which consists of four cohorts). Each line in Figure 1 represents a generation (e.g. 1947 represents all cohorts

\footnotetext{
1 We do not allocate them to the children, as is recommended by the NTA, because here we are considering only individuals over age 25 .
} 
Figure 1(a):

Disposable income by age and cohort groups, constant euros, whole population

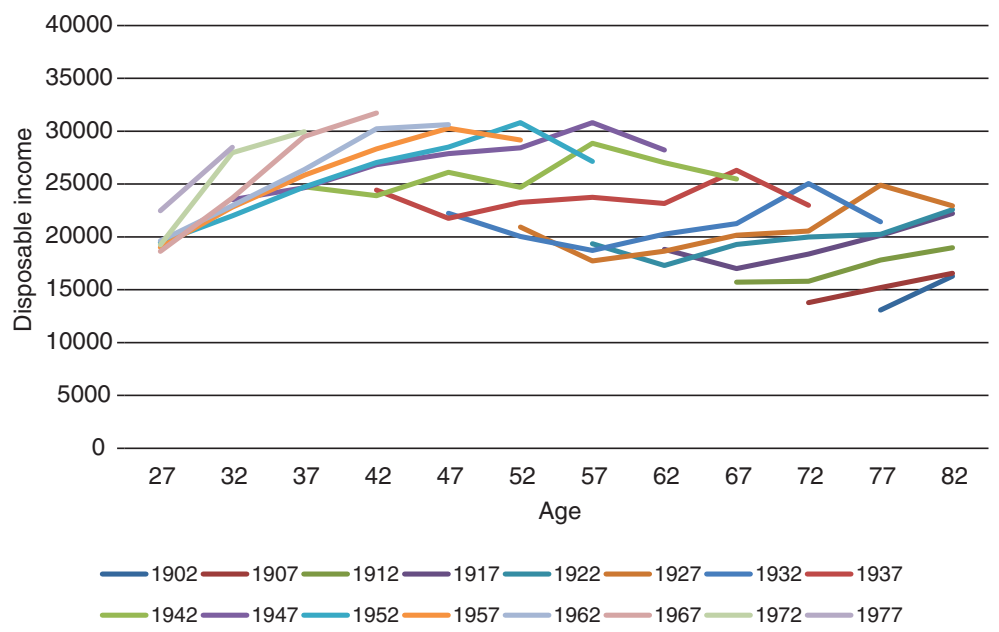

Figure 1(b):

Disposable income by age and cohort groups, constant euros, men

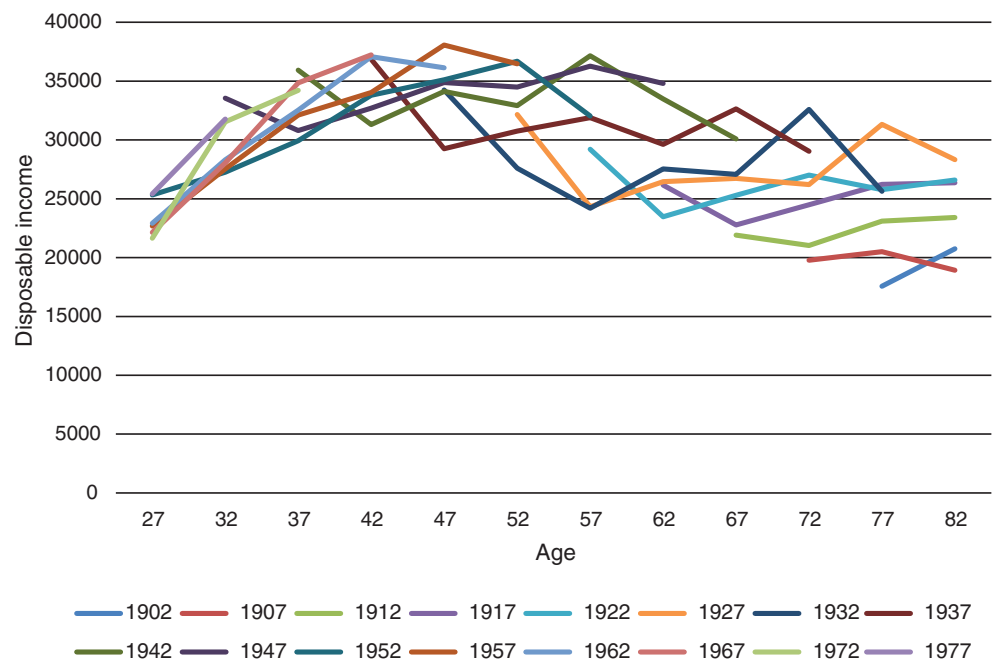

born between 1945 and 1949) at different ages (e.g. 57 represents the 55-59 age bracket).

Both for the whole population (Figure 1(a)) and for men alone (Figure 1(b)), income over the life-cycle forms an inverted U. Moreover, since the curves often 
Figure 1(c):

Disposable income by age and cohort groups, constant euros, women

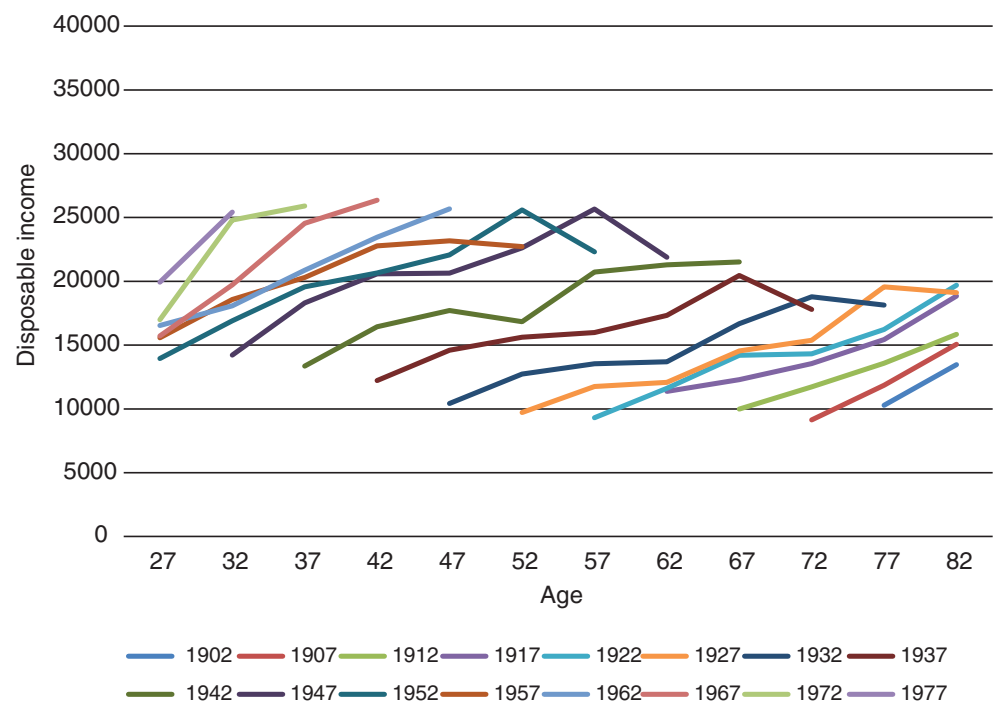

Figure 1(d):

Sex ratio of disposable incomes by age and cohort groups

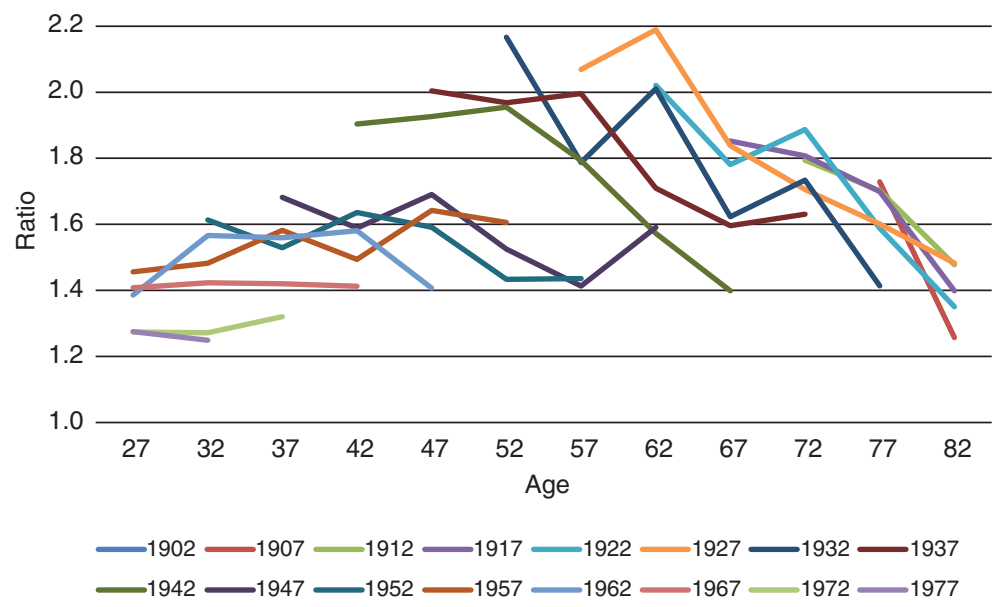

cross, it is hard to come to any conclusion about income variation from one generation to the next. However, for women alone (Figure 1(c)), income appears to rise throughout an individual's lifetime, and clearly improves from generation to generation. But regardless of the age or generation, women's income is lower than 
men's income. Figure 1(d) shows the ratio between men's and women's disposable income obtained from the data presented in Figures 1(b) and 1(c), except for the data from the 1979 survey. We can see that, for all ages and for all generations, this ratio is greater than one. Inequalities appear to decline from one generation to the next, with a sharp division emerging between those born before and after the Second World War.

\subsection{Mortality-adjusted disposable income by age and cohort}

The mortality-adjusted disposable income indicator is designed to include longevity gains by assigning them a monetary value. This value is determined by the reduction in income that would theoretically be accepted in exchange for enjoying a longer lifespan. Here, we adapt the method described in d'Albis and Bonnet (2018) by calculating the willingness to pay for a longer life at each age, and not just at birth.

Let us start with a life-cycle model with an uncertain lifespan, like those developed by Yaari (1965) and Barro and Friedman (1977), among others. The program of a representative agent of age $a=\{0,1, \ldots, T\}$ at date $t$ is to maximise an intertemporal utility:

$$
V_{a, t}=\sum_{i=a}^{T} \frac{1}{(1+\theta)^{i-a}} \frac{l_{i, t}}{l_{a, t}} u\left(c_{i, t+i-a}\right),
$$

subject to an intertemporal budget constraint:

$$
\sum_{i=a}^{T} \frac{1}{(1+r)^{i-a}} \frac{l_{i, t}}{l_{a, t}} c_{i, t+i-a}=w_{a, t}+\sum_{i=a}^{T} \frac{1}{(1+r)^{i-a}} \frac{l_{i, t}}{l_{a, t}} y_{i, t+i-a} .
$$

Variables $c_{a, t}, y_{a, t}$, and $w_{a, t}$ represent consumption income and wealth at age $a$ and date $t$. Moreover, $l_{i, t} / l_{a, t}$ is the probability of surviving to age $i$ for an individual of age $a$, which is here approximated with period life tables. Finally, $\theta$ and $r$ are the discount rate and interest rate, respectively. Assuming $\theta=r$, zero initial wealth and $y_{i, t+i-a}=y_{a, t}$, we find that the optimal consumption is constant and equal to income. The intertemporal utility can thus be written as:

$$
V_{a, t}=u\left(y_{a, t}\right) a\left(\frac{l_{i, t}}{l_{a, t}}\right),
$$

which corresponds to the product of the utility of income and the value of an annuity calculated using survival functions,

$$
a\left(\frac{l_{i, t}}{l_{a, t}}\right)=\sum_{i=a}^{T} \frac{1}{(1+r)^{i-a}} \frac{l_{i, t}}{l_{a, t}} .
$$


Following Fleurbaey and Gaulier (2009) and d'Albis and Bonnet (2018), we defined a mortality-adjusted income. The principle behind this approach is to calculate a willingness to pay, denoted $x_{a, t}$, by comparing for a given date the life expectancy at age $a$ with the life expectancy that prevails at a late date, denoted $t^{*}$. This willingness to pay corresponds to the income an individual at date $t$ would be willing to forego in order to enjoy the life expectancy at date $t^{*}$. It is calculated as follows:

$$
u\left(y_{a, t}\right) a\left(\frac{l_{i, t}}{l_{a, t}}\right)=u\left(y_{a, t}-x_{a, t}\right) a\left(\frac{l_{i, t^{*}}}{l_{a, t^{*}}}\right),
$$

where $y_{a, t}-x_{a, t}$ corresponds to our mortality-adjusted income, which solves:

$$
y_{a, t}-x_{a, t}=u^{-1}\left(\frac{u\left(y_{a, t}\right) a\left(\frac{l_{i, t}}{l_{a, t}}\right)}{a\left(\frac{l_{i, t^{*}}}{l_{a, t^{*}}}\right)}\right) .
$$

The greater the gap in life expectancy between $t$ and $t^{*}$, the lower the mortalityadjusted income. Like Becker et al. (2005) and d'Albis and Bonnet (2018), we use a Constant Relative Risk Aversion utility function:

$$
u(c)=\frac{c^{1-\frac{1}{\gamma}}}{1-\frac{1}{\gamma}}+\alpha,
$$

and choose the following parameter values: $r=0.03, \gamma=1.25$, and $\alpha=-16.2$. The last two parameters are used in Becker et al. (2005), and enable us to match Murphy and Topel (2003)'s estimates of the Value of a Statistical Life. A robustness check for an alternative set of parameters reveals that the evaluation of the willingness to pay is sensitive to those parameters, but that estimations of age and cohort effects remain qualitatively robust (see Appendix B). Moreover, the dates we consider are those of the BdF surveys; i.e. $t=1979,1984, \ldots, 2010$; while the ages are: $a=25,26, \ldots, 84$.

The life expectancy by age statistics come from the Human Mortality Database. For reasons of data availability, we use the cross-sectional data. This approach probably underestimates the rise in life expectancy, and, consequently, the benefit to the youngest generations of this rise in life expectancy. As we shall see below, this approach does not undermine our econometric results. Indeed, because it is based cautious assumptions, it strengthens them.

Figure 2 shows the increase in life expectancy at each age from 1979 to 2010 for the whole population, men alone, and women alone. In line with recent mortality trends in most other developed countries, life expectancy in France rose with age, reaching 77 for men and 82 for women (Wilmoth and Horiuchi 1999). The increase was close to $40 \%$ by these ages, and then declined. At all ages between 25 and 80, the increase was significantly greater for men than for women. 
Figure 2:

Increase in life expectancy at each age between 1979 and 2010

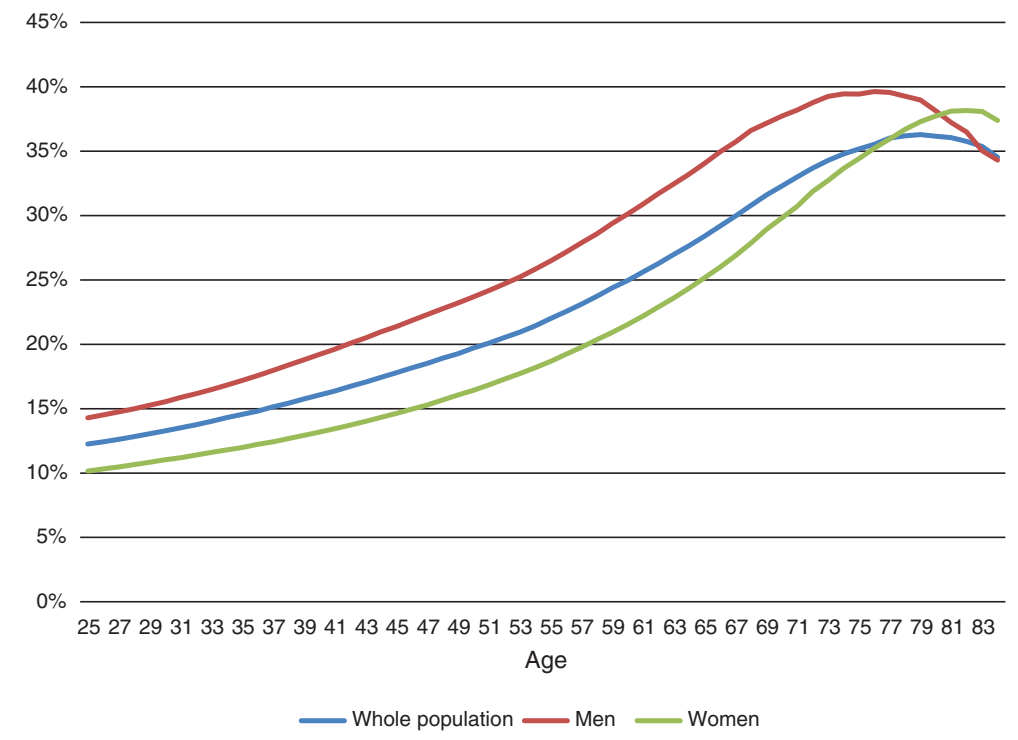

As calculated, willingness to pay was higher for men than for women, most likely because women's life expectancy increased less than that of men. Furthermore, although the willingness to pay declined from one survey to another, it was relatively constant from one age group to another. For example, the share of disposable income men said they were willing to pay in exchange for enjoying a 2010 life expectancy was around $20 \%$ in 1979, and more than $10 \%$ in 1995. The corresponding shares for women were just over $9 \%$ and $4 \%$. Figures 3(a), 3(b), and 3(c) show mortalityadjusted disposable income for, respectively, the whole population, men alone, and women alone. While the age profiles for income do not differ greatly from those in Figures 1(a), 1(b), and 1(c), the differences between the generations are clearer. Figure 3(d) also shows that the differences between men and women are smaller.

\subsection{Estimation with pseudo panel data}

Individual data can be used to distinguish the effects of age, cohort, and period, provided these are panel data that follow individuals throughout their entire lifecycle. Since our data are cross-sectional, we have built pseudo panels that group individuals belonging to the same cohort. We defined our cohorts using the "date of birth" variable, which resulted in 79 annual cohorts. The first cohort is made up of individuals who were born in 1901, and the last cohort cohort is made up 
Figure 3(a):

Mortality-adjusted disposable income by age and cohort groups, constant euros, whole population

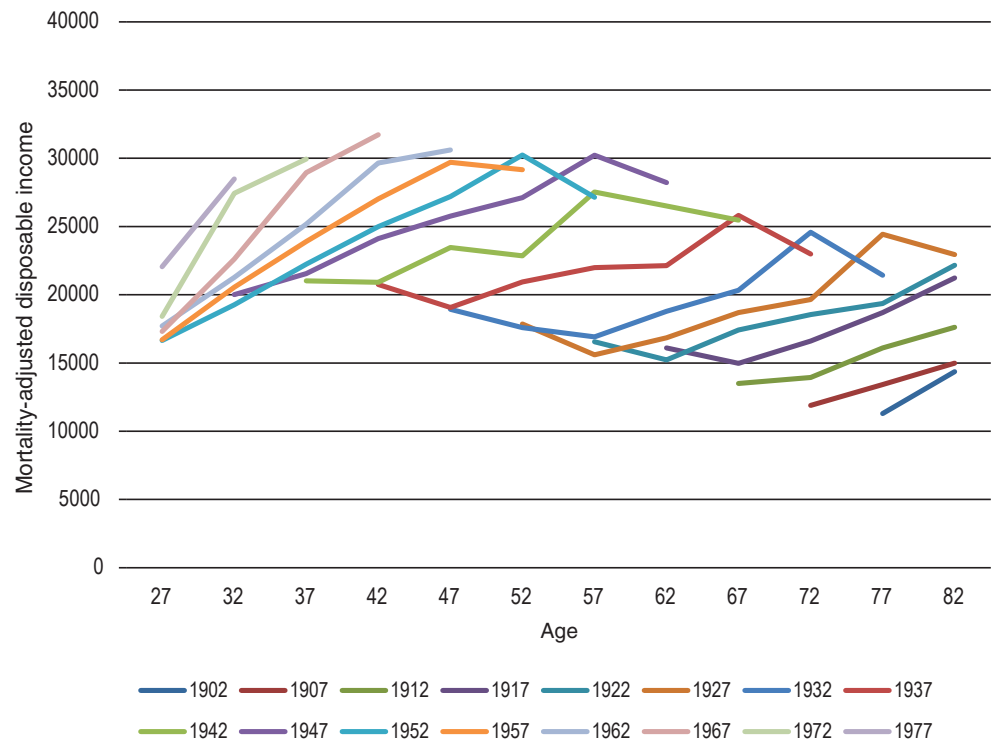

Figure 3(b):

Mortality-adjusted disposable income by age and cohort groups, constant euros, men

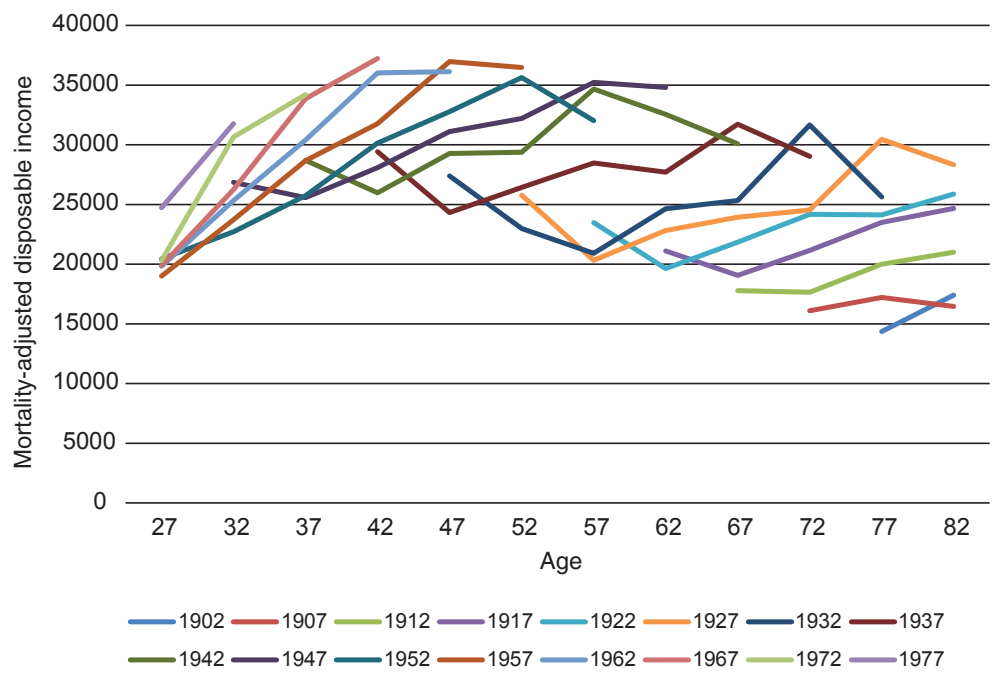


Figure 3(c):

Mortality-adjusted disposable income by age and cohort groups, constant euros, women

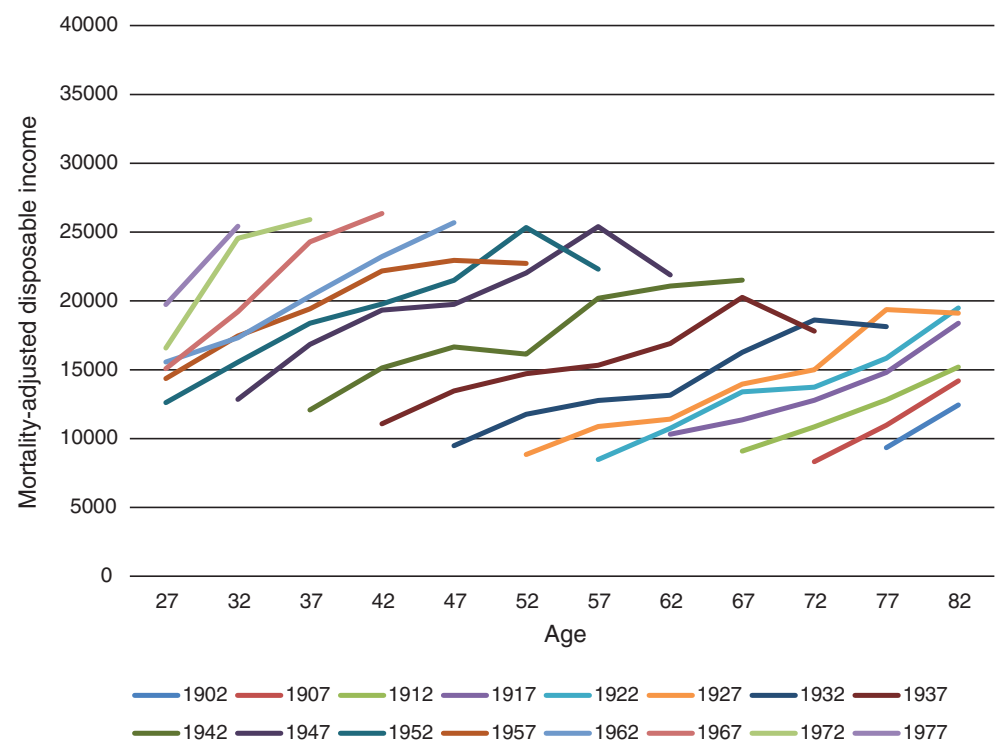

Figure 3(d):

Sex ratio of moratlity adjusted disposable incomes by age and cohort groups

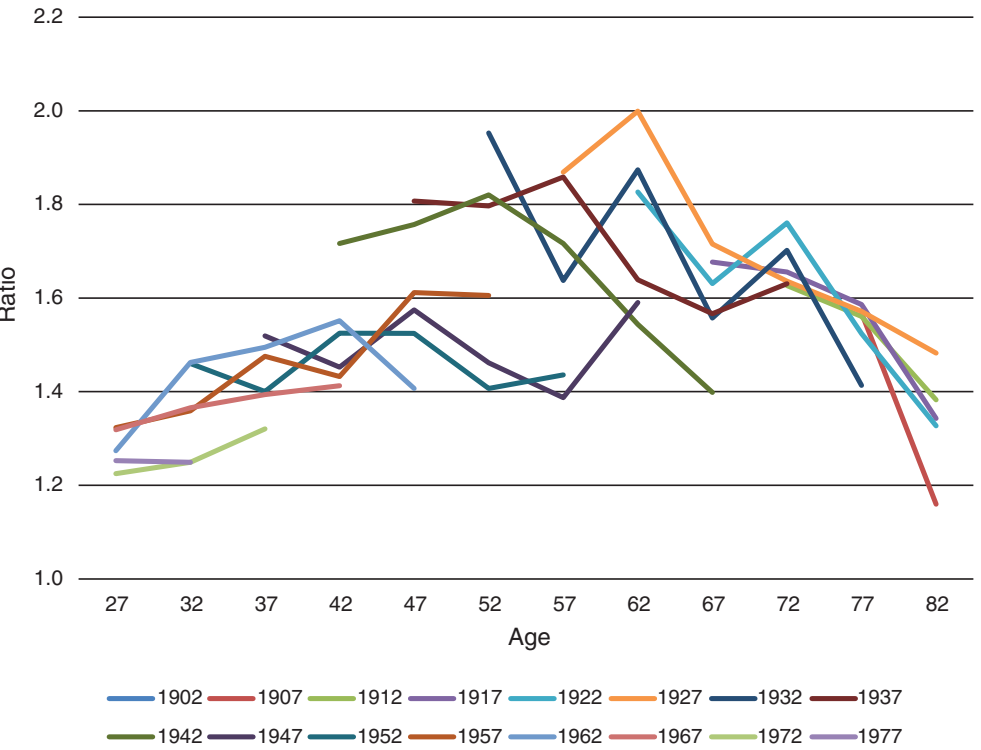


Table 1:

Size of observed cohorts

\begin{tabular}{lcrr}
\hline & All population & Women & Men \\
\hline Number of cohort observations & 407 & 407 & 407 \\
Mean size of cohorts & 288 & 150 & 138 \\
Minimal size & 39 & 24 & 15 \\
Maximal size & 574 & 305 & 277 \\
Proportion of cohorts whose size is greater than 100 & $94 \%$ & $80 \%$ & $72 \%$ \\
\hline
\end{tabular}

of individuals who were born in 1979. Our pseudo panel includes 407 observations of our cohorts, because not all cohorts were observed in each survey, and the sizes of cohorts depended on the samples used (see Table 1). The observation numbers were small mainly for the older cohorts, and particularly for men, as their life expectancy was lower.

The simultaneous introduction of the "age", "cohort", and "period" variables in the estimation creates a collinearity problem because the survey year is equal to the sum of the "age" and "cohort" variables. As was noted in d'Albis and Badji (2017), various solutions to this problem have been proposed in the literature. We have chosen to follow the most common strategy: namely, that of Deaton and Paxson (1994). This approach imposes restrictions on the estimated parameters based on the assumption that period effects sum to zero, and are orthogonal to the long-term trend.

We assume that the three effects (age, cohort, and period) that we are seeking to estimate are additive. The model equation is written as follows:

$$
\log \bar{y}_{j t}=\mu+\sum_{i} \alpha_{i} 1_{a_{j t}}+\sum_{c} \beta_{c} 1_{j=c}+\sum_{t} \gamma_{t} 1_{t=p}+\bar{\varepsilon}_{j t}
$$

where $\bar{y}_{j t}$ represents the explained variable related to cohort $j=1901$, $1902, \ldots, 1979$ and survey dates $t=1979,1984, \ldots, 2010,1_{\text {ajt }}$ represent the indicators of the five-year age brackets from 25-29 years old to 80-84 years old associated with cohort $j$ at date $t, 1_{j=c}$ represent the indicators of the cohorts, and $1_{t=p}$ represent the indicators associated with survey dates $t$.

We estimated our equation for each of the variables of interest: disposable income and mortality-adjusted disposable income, both for the whole population and for men and women separately. Looking at Table 2, we can see that in all instances, the tests for fixed individual effects (which in our case are cohort effects, given by the term $\sum_{c} \beta_{c} 1_{j=c}$ ) were positive, which justifies our choice of a fixed effects model. More precisely, we estimated a Least Square Dummy Variable type fixed effects model. 
Table 2:

Test for fixed individual effects and Hausman test

\begin{tabular}{lccccc}
\hline & \multicolumn{2}{c}{ Individual effects test } & & \multicolumn{2}{c}{ Hausman test } \\
& F-statistic & P-value & & F-statistic & P-value \\
\hline Disposable income & & & & & \\
$\quad$ All population & 17.15 & 0.00 & & 300.80 & 0.00 \\
$\quad$ Men & 5.76 & 0.00 & & 229.98 & 0.00 \\
$\quad$ Women & 28.22 & 0.00 & & 329.92 & 0.00 \\
Mortality-adjusted disposable income & & & & & \\
$\quad$ All population & 30.01 & 0.00 & & 334.58 & 0.00 \\
$\quad$ Men & 14.13 & 0.00 & & 286.38 & 0.00 \\
$\quad$ Women & 35.84 & 0.00 & & 341.83 & 0.00 \\
\hline
\end{tabular}

\section{Results}

We now present our results by analysing in turn the cohort and the age effects on the two income measures presented above. We then provide a general discussion of the results. Period effects are not discussed here because they are not directly related to the research question of this article. All estimates are given in Appendix A.

\subsection{Comparisons of incomes across cohorts}

Figures 4, 5, and 6 represent the logarithm of the two incomes we consider as functions of the birth date when we control for age and period effects. Figure 7 covers the whole population, whereas Figures 8 and 9 refer to men and women, respectively. In each figure, panel (a) is the logarithm of the disposable income, and panel (b) is the logarithm of the mortality-adjusted disposable income. The results are expressed as a deviation from a reference cohort; i.e. the cohort born in 1946. Moreover, the grey lines delimit the confidence interval at the 5\% level.

When we consider the whole population (Figure 4), we can discern two major periods in the development of disposable income by date of birth. Among the cohorts born before the Second World War, incomes increased significantly from generation to generation: from the 1926 cohort to the 1946 cohort, incomes rose $40 \%$. But among the post-war cohorts, there were no significant changes. A slight increase can be observed for the latest cohorts. However, since there is less information on these cohorts in our databases, this finding should not be given too much importance. The observation that disposable income has stagnated suggests that that the baby boom cohorts in particular have not had higher living standards 
Figure 4(a):

Log of disposable income (values relative to cohort 1946) as a function of the date of birth, whole population

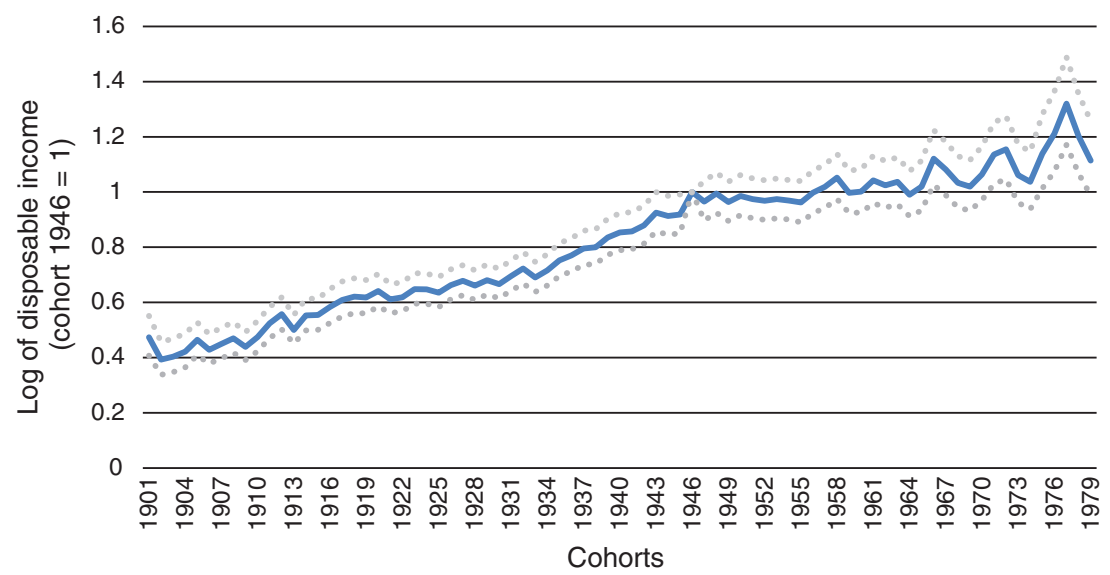

Note: The dotted curves show the confidence intervals at 95\%. Model controlled for the age group and the period.

Figure 4(b):

Log of mortality adjusted disposable income (values relative to cohort 1946) as a function of the date of birth, whole population

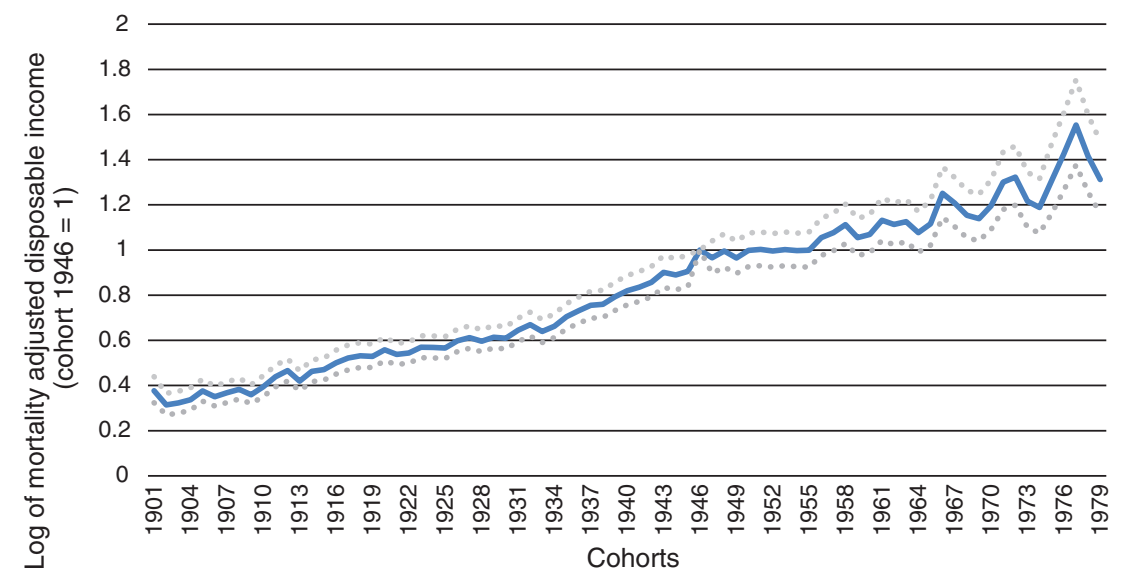

Note: The dotted curves show the confidence intervals at $95 \%$. Model controlled for the age group and the period. 
Figure 5(a):

Log of disposable income (values relative to cohort 1946) as a function of the date of birth, men

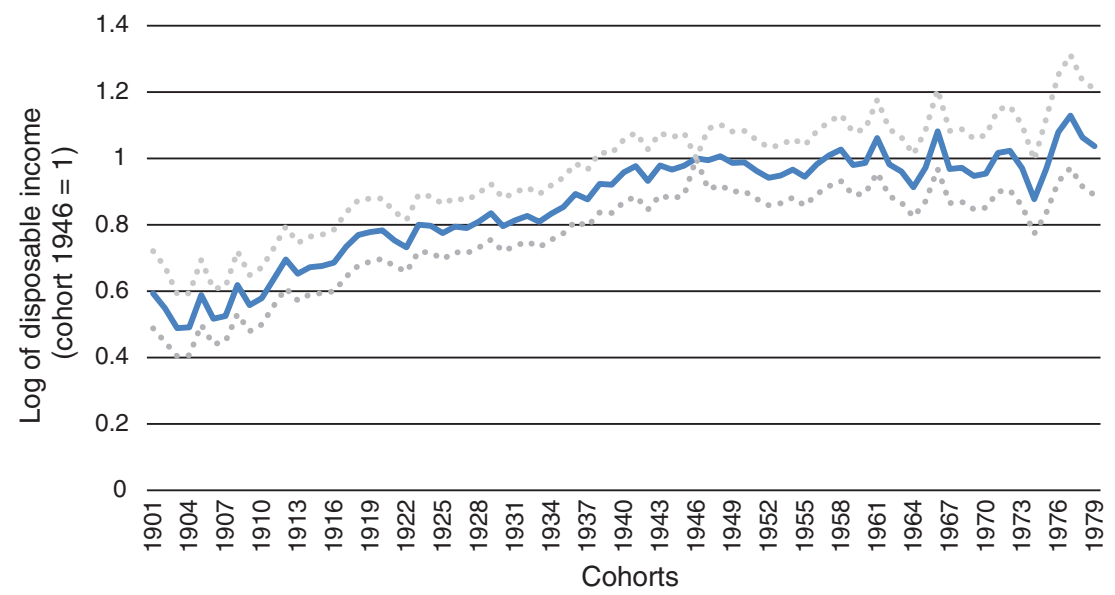

Note: The dotted curves show the confidence intervals at $95 \%$. Model controlled for the age group and the period.

Figure 5(b):

Log of mortality adjusted disposable income (values relative to cohort 1946) as a function of the date of birth, men

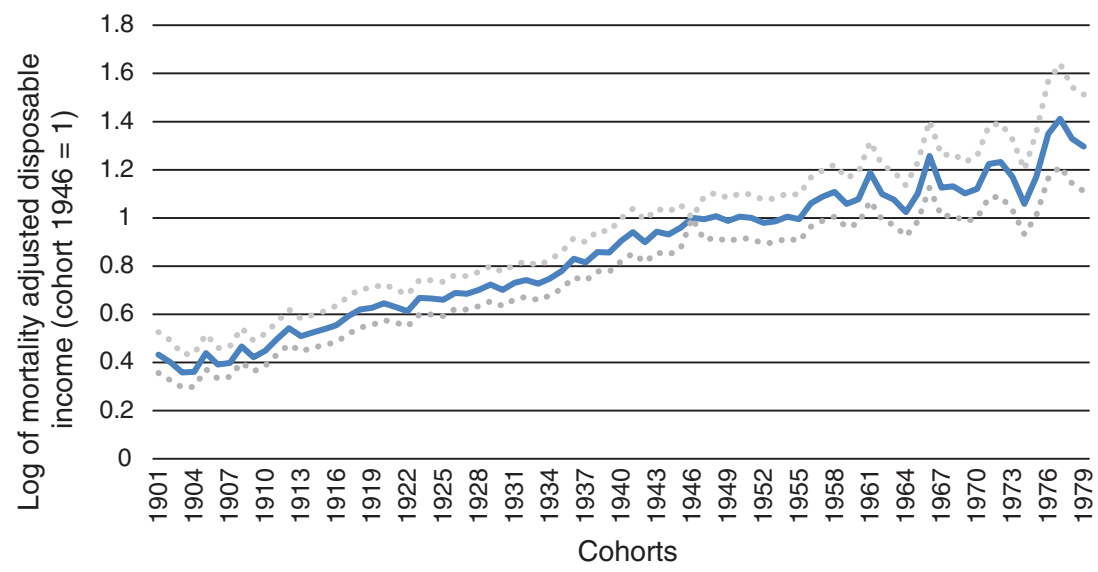

Note: The dotted curves show the confidence intervals at $95 \%$. Model controlled for the age group and the period. 
Figure 6(a):

Log of disposable income (values relative to cohort 1946) as a function of the date of birth, women

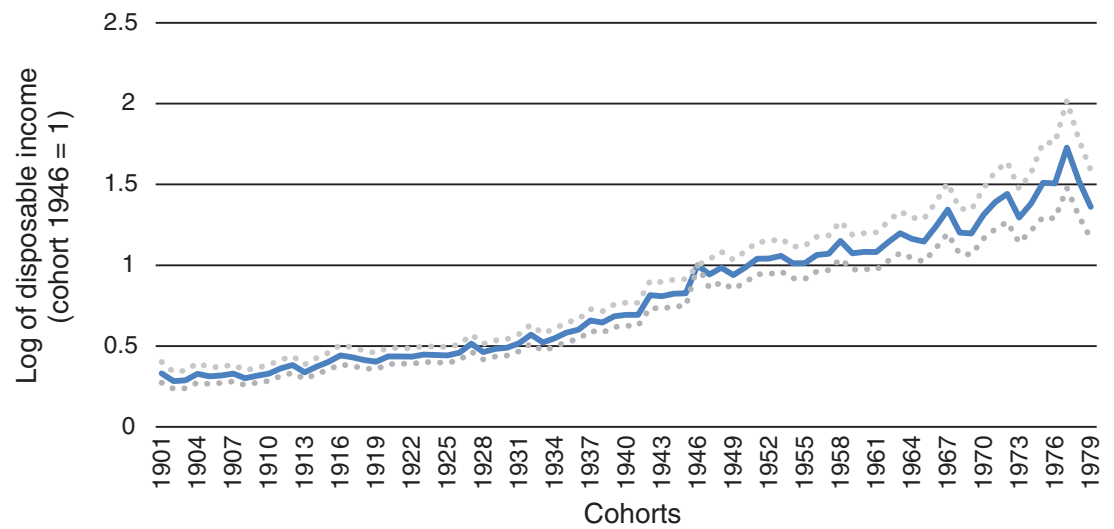

Note: The dotted curves show the confidence intervals at 95\%. Model controlled for the age group and the period.

Figure 6(b):

Log of mortality adjusted disposable income (values relative to cohort 1946) as a function of the date of birth, women

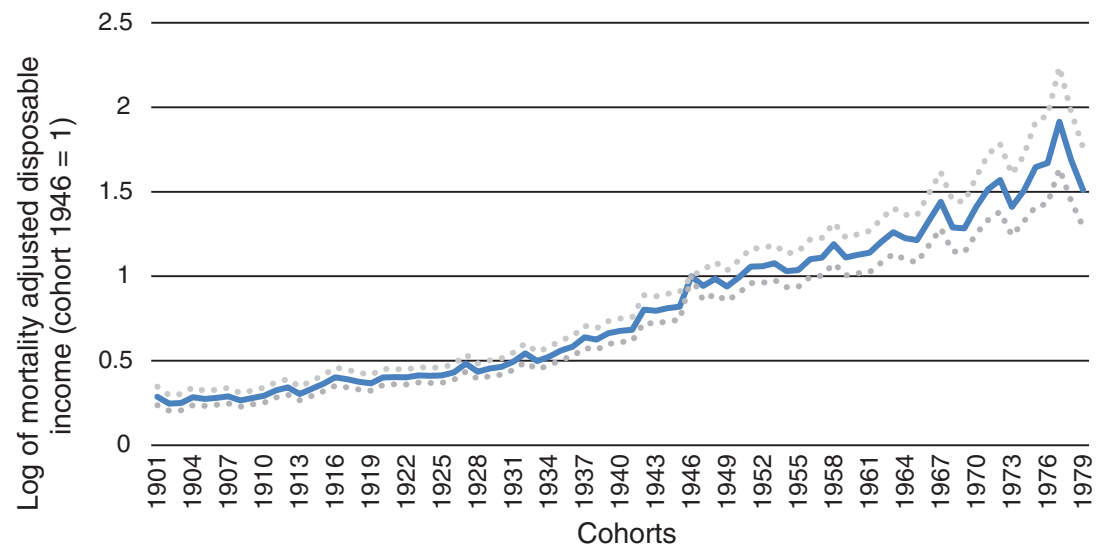

Note: The dotted curves show the confidence intervals at 95\%. Model controlled for the age group and the period. 
Figure 7(a):

Log of disposable income (values relative to age 47) as a function of the age group, whole population

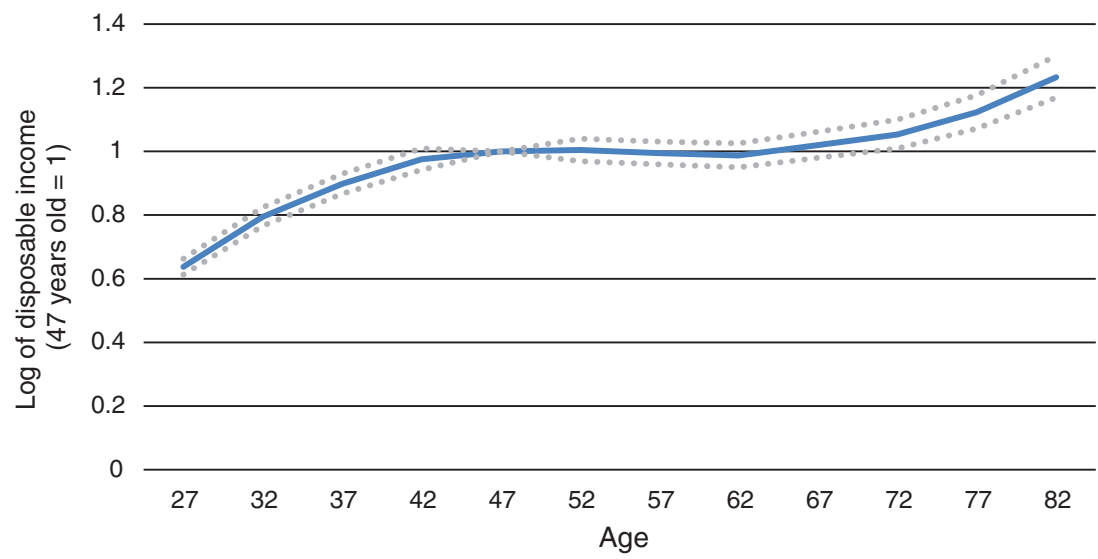

Note: The dotted curves show the confidence intervals at $95 \%$. Model controlled for the date of birth and the period.

\section{Figure 7(b):}

Log of mortality-adjusted disposable income (values relative to age 47) as a function of the age group, whole population

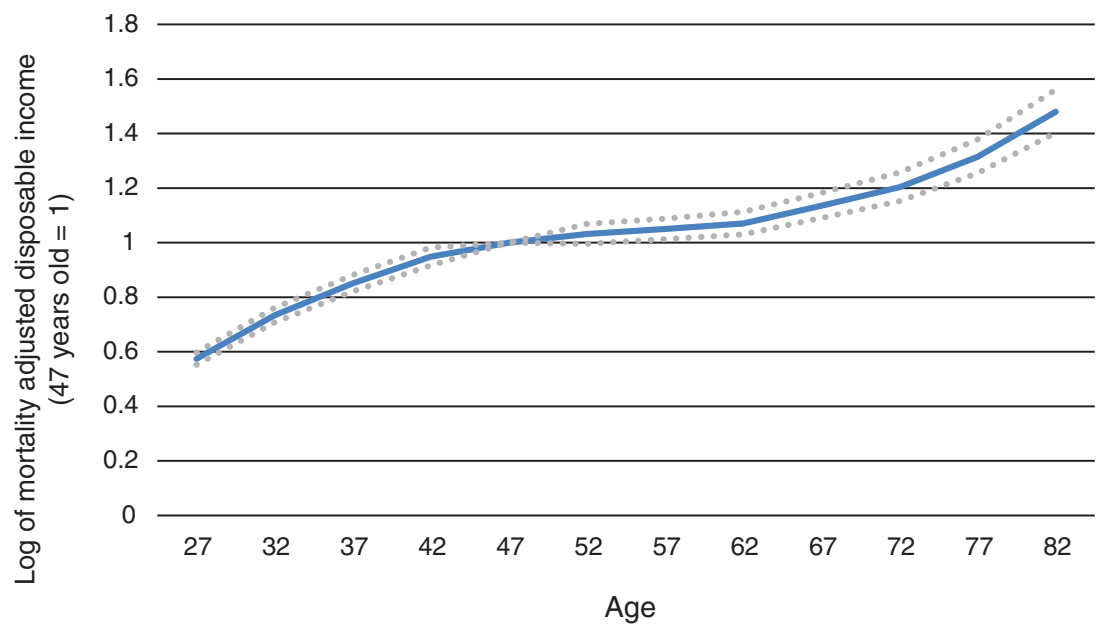

Note: The dotted curves show the confidence intervals at $95 \%$. Model controlled for the date of birth and the period. 
Figure 8(a):

Log of disposable income (values relative to age 47) as a function of the age group, men

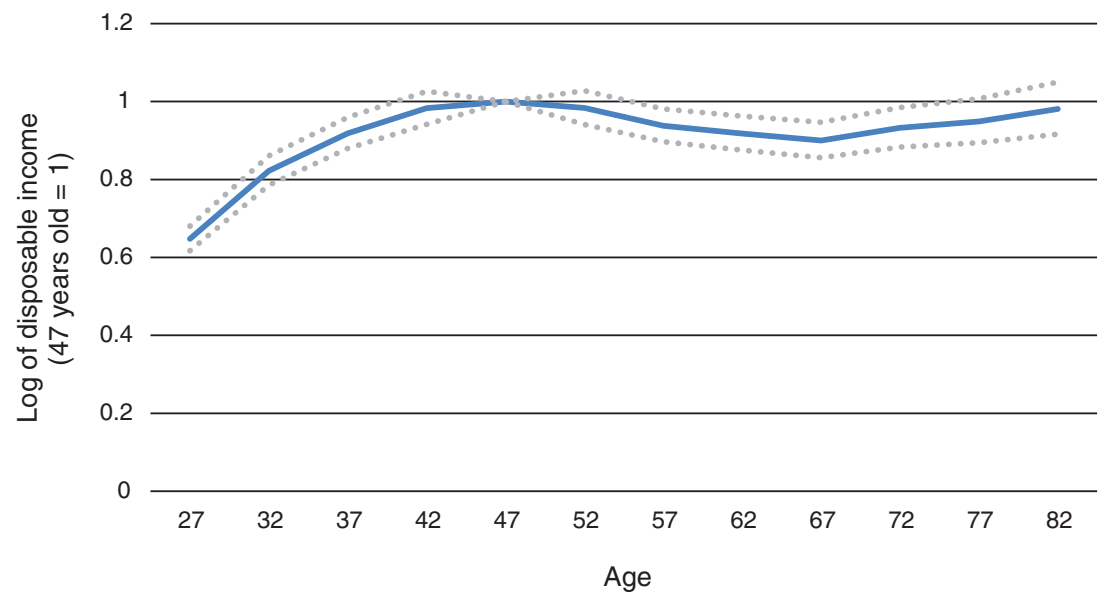

Note: The dotted curves show the confidence intervals at 95\%. Model controlled for the date of birth and the period.

\section{Figure 8(b):}

Log of mortality-adjusted disposable income (values relative to age 47) as a function of the age group, men

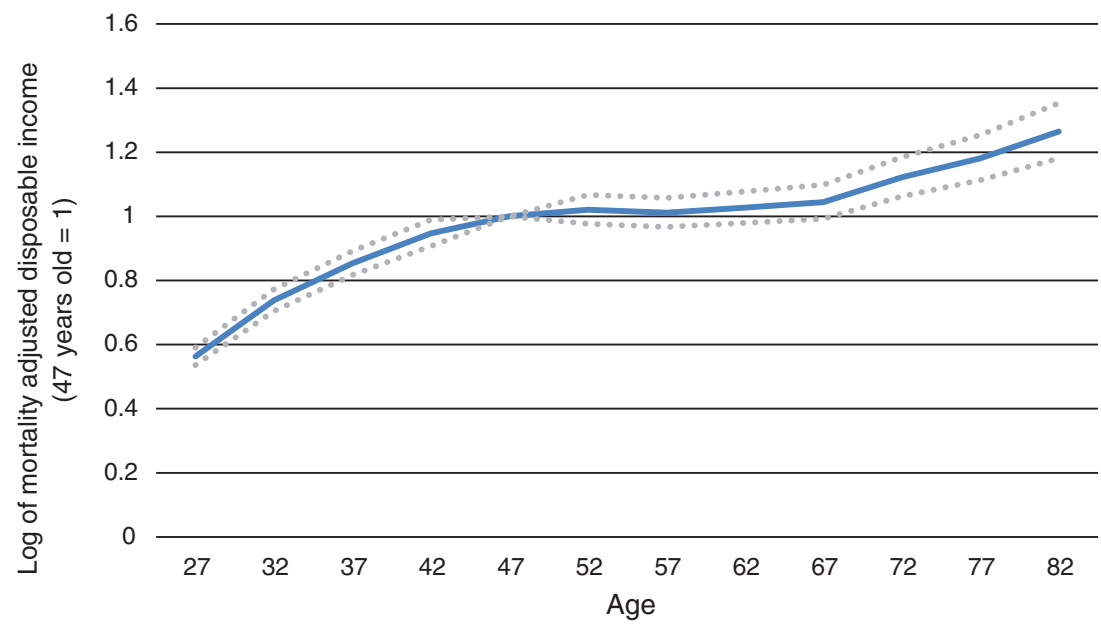

Note: The dotted curves show the confidence intervals at 95\%. Model controlled for the date of birth and the period. 
Figure 9(a):

Log of disposable income (values relative to age 47) as a function of the age group, women

$$
2.5
$$

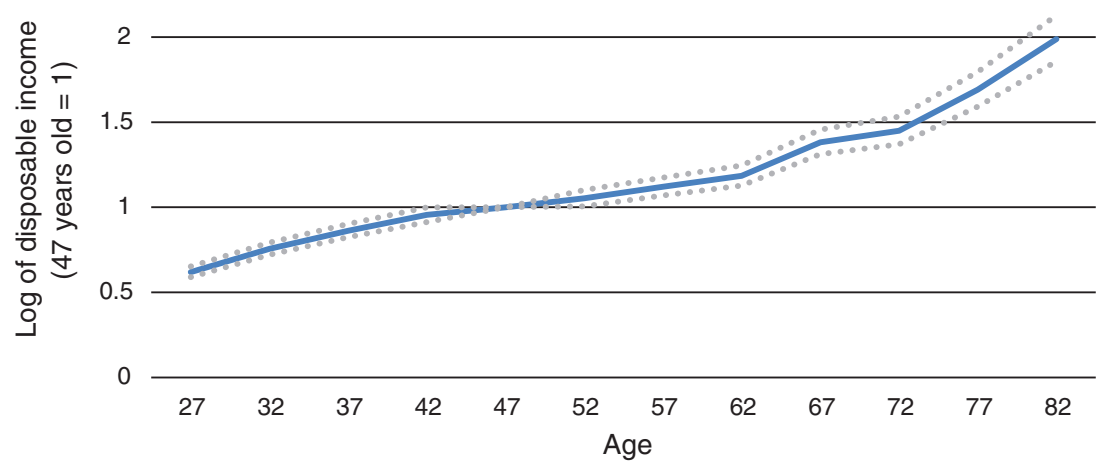

Note: The dotted curves show the confidence intervals at 95\%. Model controlled for the date of birth and the period.

Figure 9(b):

Log of mortality-adjusted disposable income (values relative to age 47) as a function of the age group, women

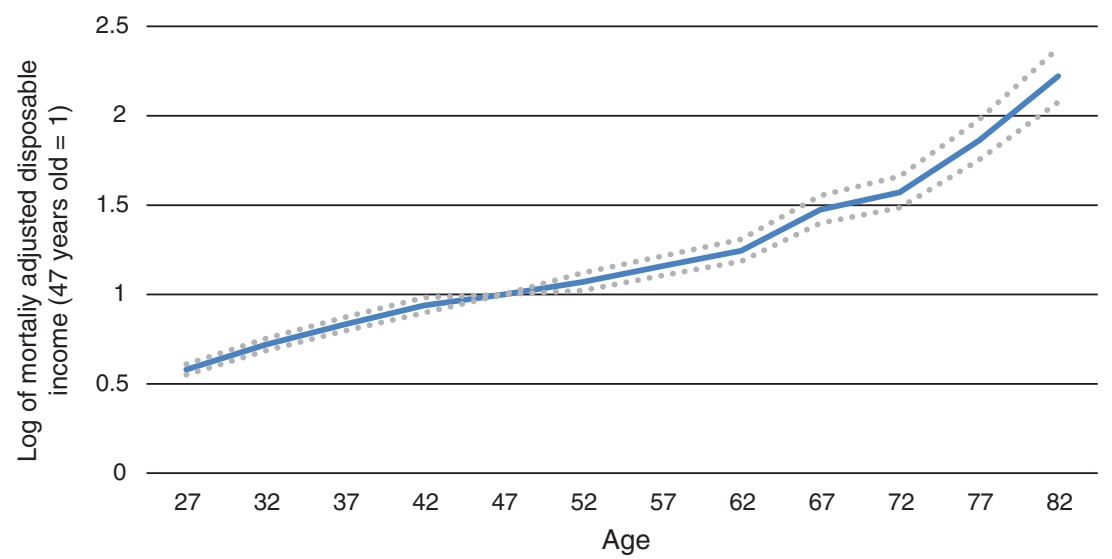

Note: The dotted curves show the confidence intervals at $95 \%$. Model controlled for the date of birth and the period. 
than subsequent cohorts (d'Albis and Badji 2017). When the gains from higher life expectancy are added, the distinction between these two periods becomes much less clear. Mortality-adjusted disposable income increased throughout the study period. In particular, we can see that all of the cohorts born after 1960 have enjoyed significantly higher incomes than the cohort born in 1946. We find, for example, that mortality-adjusted disposable income rose $28.6 \%$ from the 1946 cohort to the 1966 cohort, compared to $49.4 \%$ from the 1926 to the 1946 cohort. It thus appears that, ultimately, all of the post-baby boom cohorts had a higher adjusted income than the baby boomers. Note that our results are reinforced when using private consumption rather that disposable income (see Appendix B).

The breakdown by sex is also highly instructive. The variation in disposable income has been much flatter for the male population (Figure 5) than for the population as a whole. The increase observed among the pre-war cohorts is less pronounced, and no further relative improvement can be seen from the 1946 cohort to the 1970s cohorts. Including life expectancy gains hardly alters this observation, although we do find that the increase was greater for the pre-war cohorts, and that some post-baby boom cohorts had a significantly higher mortality-adjusted income than the 1946 cohort.

The results for the female population differ dramatically from those for the male population (Figure 6). Even before we include life expectancy gains, we see a considerable increase. For example, we find that disposable income for women rose $27 \%$ from the 1946 cohort to the 1966 cohort, compared to $71.9 \%$ from the 1926 cohort to the 1946 cohort. Furthermore, we can see that all of the cohorts born after 1961 had significantly higher incomes than the 1946 cohort. When life expectancy gains are included, these increases are slightly greater: i.e. mortalityadjusted disposable income for women rose $38.8 \%$ from the 1946 cohort to the 1966 cohort, and $76.6 \%$ from the 1926 cohort to the 1946 cohort.

It is of interest to note that recent studies of intergenerational mobility have focused on men alone. Lefranc (2018) has shown that the intergenerational persistence of income has increased starting with the cohorts born in the 1950s; while Alesina et al. (2018) has found that the French, like other Europeans, are pessimistic about intergenerational mobility. Our results suggest that the positions of men are not representative of the positions of the population as a whole; and, thus, that focusing on men's experiences conceals the improvements women have enjoyed. Moreover, as those two studies used data from the same survey (Formation et Qualification Professionnelle), which does not contain explicit information on income, the authors had to estimate income. Using the same survey to study intergenerational mobility through social classes, Vallet (2017) concluded that mobility increased for the younger cohorts, and that improvements were larger for women than for men; while Ben-Halima et al. (2014) showed that the degree of intergenerational persistence was less pronounced for daughters than for sons. The 
findings of both of these studies complement our results, which highlight the role of education in the reduction in intergenerational inequalities.

\subsection{Comparisons of incomes across age groups}

Figures 7, 8, and 9 represent the logarithm of the two incomes we consider as functions of the age when we control for cohort and period effects. Figure 7 covers the whole population, whereas Figures 8 and 9 display the findings for men and women, respectively. In each figure, the left panel is the logarithm of the disposable income, and the right panel is the logarithm of the mortality-adjusted disposable income. The results are expressed as a deviation from a reference age group of 4549-year-olds. As above, the grey lines delimit the confidence interval at the 5\% level.

Looking at the population as a whole (Figure 7), we can see that disposable income by age increased sharply $(+43.7 \%)$ from ages 27 to $47,{ }^{2}$ levelled out up to age 62 , and then rose moderately $(+27.9 \%)$ up to age 82 . Note that this general increase in disposable income differs greatly from the pattern implied by the descriptive statistics in Figure 1(a). After controlling for cohort and period effects, the perceived dip in income after age 50 disappears, and indeed turns into an improvement. The rise in income after age 62 may be explained by a composition effect similar to the one described in the literature on the missing poor in the poverty statistics (Kanbur and Mukherjee 2007). Since longevity correlates with income, the proportion of low-income people tends to decline from one higher age group to the next.

When longevity gains are included, we find that income growth was continuous over a lifetime; and, indeed, rose later in life. Adjusted growth was 53\% from ages 27 to $47,7.3 \%$ from ages 47 to 62 , and $50.1 \%$ from ages 62 to 82 . Thus, we can see that the gains have been particularly large for the oldest people. These observations are in line with evidence indicating that since the late 1970s, life expectancy gains in France have occurred mainly at higher ages.

The breakdown of these results by sex uncovers wide disparities between men and women. Men's disposable income (Figure 8) stopped rising after age 52, and was even significantly lower from ages 57 to 77 than at age 47 . By age 67 , men's income had declined 9.5\%. By contrast, women's disposable income (Figure 9) rose continuously, increasing $46.3 \%$ from ages 27 to $47,20.3 \%$ from ages 47 to 62 , and $123 \%$ from ages 62 to 82 . Including longevity gains greatly alters the curve of men's income by age, which was significantly higher after age 67 than it was at age 47. Taking these gains into account also increases the slope of the curve of women's income.

2 For ease of viewing, we have named each age group after its median. Thus, the 25-29 age group is named 27. 


\subsection{Discussion}

A number of conclusions may be drawn from our estimates. The first is that there can be inequality between age groups without any generation losing out. None of the income by age curves presented in Section 3.2 slopes downwards: in most cases, the slopes rise, and a few level out (or fall slightly) during part of the life-cycle. This observation implies that, on average, a person of a given age has an income that is higher than or equal to that of a younger person, after controlling for cohort and period effects. But the finding that young people are less rich than current seniors does not mean that they lose out: in all of our estimates, their income was always found to be higher than or equal to that of members of previous generations at the same age. d'Albis and Badji (2017) attributed this pattern to economic growth. Although the growth in real per capita GDP was less vigorous between 1979 and 2010 than it was during the 30 years that followed the Second World War, it still increased $50 \%$ over this period.

Including longevity gains only supported this observation. After these gains were added, hardly any periods of stagnation in mortality-adjusted disposable income remained: in all of our models, that indicator rose as a function both of age and year of birth. This is likely because life expectancy at birth rose from 1979 to 2010 (10\% to $40 \%$, depending on age and sex), which added to the effect of economic growth. Thus, it is clear that well-being, which was measured here by combining an economic and a demographic indicator, improved both over a lifetime and from one generation to the next. If we assume that equity between generations is ensured as long as their well-being does not deteriorate (Stavins et al. 2003; Arrow et al. 2004), we can conclude that the relative positions of the French cohorts born from 1901 to 1979 have been equitable.

However, our breakdown of the population into men and women has led us to qualify this observation. It is clear that most of the gains in mortality-adjusted disposable income have gone to women, whose economic positions greatly improved over this period. Conversely, the mortality-adjusted disposable income levels of men varied little for all of the cohorts born after the Second World War. Thus, while men's well-being has not worsened, it has not improved as much as that of women. This point in no way detracts from the reality that men continue to have much higher disposable income than women (for example, among 52-year-olds in 2010, men's income levels were $60 \%$ higher than women's). Our observations merely reveal that women's earnings are catching up to those of men.

\section{Concluding remarks}

In this article, we examined the variation in well-being across the generations and across different ages in France. We constructed a composite indicator that assigns a monetary value to life expectancy gains in order to obtain mortality-adjusted disposable income. We showed that, generally speaking, this indicator has increased 
from generation to generation. However, a breakdown by sex revealed that the position of women has improved considerably, while that of men has stagnated for all of the cohorts born after the Second World War. Over a life-cycle, this indicator has generally risen. From a public policy perspective, these results suggest that reducing the benefits of the elderly based on the assumption that they are advantaged relative to young people is not well grounded. Thus, reducing the living standards of baby boomers may not be equitable.

This research could be improved by including other dimensions of well-being. Leisure is obviously a major constituent of well-being (Jones and Klenow 2016). It is likely that the centuries-long reduction in working hours that has occurred across the developed countries (Boppart and Krusell 2016) has led to an increase in leisure time from one generation to the next. This would tend to support our basic conclusions that the well-being of generations has not declined, and that equity between the generations has been preserved. It would, however, be useful to examine how these developments have differed for men and women by taking into account the time spent on domestic production. This cannot be done with $\mathrm{BdF}$ survey data alone. Unfortunately, the main time use survey in France, the Emploi $d u$ Temps, covers a much shorter period (d'Albis et al. 2016). An additional avenue for future research would be income inequality. Here it would be useful to distinguish between general inequality and inequality by age, and to determine which of these forms of inequality has the greatest impact on individual well-being. Similarly, we may want to decompose our estimation by socio-economic status. These further questions are on our research agenda.

\section{Acknowledgments}

The authors thank two referees of this journal for their comments. Financial support from the Agence nationale de la recherche within the JPI MYBL framework (Award no. ANR-16-MYBL-0001-02) is gratefully acknowledged.

\section{References}

d'Albis, H. and I. Badji 2017. Intergenerational inequalities in standards of living in France. Economics and Statistics 491-492: 71-92.

d'Albis, H. and F. Bonnet 2018. Inequality in life expectancy and the global welfare convergence. Economics Letters 168: 49-51.

d'Albis, H., C. Bonnet, J. Navaux, J. Pelletan, H. Toubon and F.-C. Wolff 2015. The lifecycle deficit for France, 1979-2005. Journal of the Economics of Ageing 5: 79-85.

d'Albis, H., C. Bonnet, J. Navaux, J. Pelletan and F.-C. Wolff 2016. Travail rémunéré et travail domestique: une évaluation monétaire de la contribution des femmes et des hommes à l'activité économique depuis 30 ans. Revue de l'OFCE 149: 101-130. 
d'Albis, H., C. Bonnet, J. Navaux, J. Pelletan and F.-C. Wolff 2017. Lifecycle deficit in France: An assessment for the period 1979-2011. Economics and Statistics 491-492: 47-70.

Alesina, A., S. Stantcheva and E. Teso 2018. Intergenerational mobility and preferences for redistribution. American Economic Review 108(2): 521-554.

Arrow, K., P. Dasgupta, L. Goulder, G. Daily, P. Ehrlich, G. Heal, S. Levin, K.-G. Mäler, S. Schneider, D. Starrett and B. Walker 2004. Are we consuming too much? Journal of Economic Perspectives 18(3): 147-172.

Barro, R. J. and J. W. Friedman 1977. On uncertain lifetimes. Journal of Political Economy 85(4): 843-849.

Becker, G. S., T. J. Philipson and R. R. Soares 2005 . The quantity and quality of life and the evolution of world inequality. American Economic Review 95(1): 277-291.

Ben-Halima, B., N. Chusseau and J. Hellier 2014. Skill premia, and intergenerational education mobility: The French case. Economics of Education Review 39: 50-64.

Boppart, T. and P. Krusell 2016. Labor Supply in the Past, Present, and Future: A BalancedGrowth Perspective. NBER Working Paper No. 22215.

Deaton, A. 2013. The great escape. Health, wealth, and the origins of inequality. Princeton University Press.

Deaton, A. and C. Paxson 1994. Saving, growth, and aging in Taiwan. Chicago University Press for National Bureau of Economic Research.

Fleurbaey, M. and G. Gaulier 2009. International comparisons of living standards by equivalent incomes. The Scandinavian Journal of Economics 111(3): 597-624.

Human Mortality Database. University of California, Berkeley (USA), and Max Planck Institute for Demographic Research (Germany). Available at www.mortality.org or www. humanmortality.de (data downloaded on May 12, 2018).

Jones, C. and P. Klenow 2016. Beyond GDP? Welfare across countries and time. American Economic Review 106(9): 2426-2457.

Kanbur, R. and D. Mukherjee 2007. Premature mortality and poverty measurement. Bulletin of Economic Research 59(4): 0307-3378.

Lefranc, A. 2018. Intergenerational earnings persistence and economic inequality in the long run: Evidence from French cohorts, 1931-75. Economica 85(340).

Murphy, K. M. and R. Topel 2003. The economic value of medical research. In Measuring the gains from medical research: An economic approach, ed. Kevin M. Murphy and Robert H. Topel, The University of Chicago Press.

Stavins, R., A. Wagner and G. Wagner 2003. Interpreting sustainability in economic terms: Dynamic efficiency plus intergenerational equity. Economics Letters 79: 339-343.

United Nations 2013. National transfer accounts manual. Measuring and analysing the generational economy. New York.

Vallet, L.-A. 2017. Mobilité sociale entre générations et fluidité sociale en France. Le rôle de l'éducation. Revue de l'OFCE 150(1): 27-67.

Yaari, M. E. 1965. Uncertain lifetime, life insurance, and the theory of the consumer. The Review of Economic Studies 32(2): 137-150.

Wilmoth, J. and S. Horiuchi 1999. Rectangularization revisited: Variability of age at death within human populations. Demography 36: 475-495. 


\section{Appendix A: Estimation results}

We present our estimation results below. The explanatory variables are the age, the cohort, and the period, while the independent variable is the logarithm of the disposable income (Model M1) and the logarithm of the mortality-adjusted disposable income (Model M2). Data sources are the authors' own calculations using waves 1979, 1984, 1989, 1995, 2000, 2005, and 2010 of the French Household Expenditure survey (enquêtes Budget de famille) from the Insee. In all tables, standard errors are in parentheses, and significance is denoted as follows: ${ }^{* * *} p<$ $0.01,{ }^{* *} p<0.05,{ }^{*} p<0.10$. 


\begin{tabular}{|c|c|c|c|c|c|c|}
\hline \multirow[b]{2}{*}{ Variables } & \multicolumn{2}{|c|}{ Whole population } & \multicolumn{2}{|c|}{ Women } & \multicolumn{2}{|c|}{ Men } \\
\hline & M1 & M2 & M1 & M2 & M1 & M2 \\
\hline \multicolumn{7}{|c|}{ Age effects } \\
\hline $25-29$ & $\begin{array}{c}-0.45^{* * *} \\
(0.020)\end{array}$ & $\begin{array}{c}-0.55^{* * *} \\
(0.020)\end{array}$ & $\begin{array}{c}-0.48^{* * *} \\
(0.026)\end{array}$ & $\begin{array}{c}-0.55^{* * *} \\
(0.026)\end{array}$ & $\begin{array}{c}-0.43^{* * *} \\
(0.025)\end{array}$ & $\begin{array}{c}-0.57^{* * *} \\
(0.025)\end{array}$ \\
\hline $30-34$ & $\begin{array}{c}-0.23^{* * *} \\
(0.019)\end{array}$ & $\begin{array}{c}-0.31^{\text {*** }} \\
(0.019)\end{array}$ & $\begin{array}{c}-0.28^{* * *} \\
(0.024)\end{array}$ & $\begin{array}{c}-0.33^{* * *} \\
(0.024)\end{array}$ & $\begin{array}{c}-0.20^{* * *} \\
(0.023)\end{array}$ & $\begin{array}{c}-0.30^{\text {*** }} \\
(0.023)\end{array}$ \\
\hline $35-39$ & $\begin{array}{c}-0.11^{* * *} \\
(0.018)\end{array}$ & $\begin{array}{c}-0.16^{* * *} \\
(0.018)\end{array}$ & $\begin{array}{c}-0.15^{* * *} \\
(0.023)\end{array}$ & $\begin{array}{c}-0.18^{* * *} \\
(0.023)\end{array}$ & $\begin{array}{c}-0.08^{* * *} \\
(0.022)\end{array}$ & $\begin{array}{c}-0.16^{* * *} \\
(0.022)\end{array}$ \\
\hline $40-44$ & $\begin{array}{c}-0.03 \\
(0.018)\end{array}$ & $\begin{array}{c}-0.05^{* * *} \\
(0.018)\end{array}$ & $\begin{array}{r}-0.05^{* *} \\
(0.023)\end{array}$ & $\begin{array}{c}-0.06^{* * *} \\
(0.023)\end{array}$ & $\begin{array}{c}-0.02 \\
(0.022)\end{array}$ & $\begin{array}{r}-0.05^{* *} \\
(0.022)\end{array}$ \\
\hline $45-49$ & Ref & Ref & Ref & Ref & Ref & Ref \\
\hline $50-54$ & $\begin{array}{c}0.00 \\
(0.018)\end{array}$ & $\begin{array}{c}0.03^{*} \\
(0.018)\end{array}$ & $\begin{array}{c}0.05^{* *} \\
(0.023)\end{array}$ & $\begin{array}{c}0.07^{* * *} \\
(0.023)\end{array}$ & $\begin{array}{c}-0.02 \\
(0.022)\end{array}$ & $\begin{array}{c}0.02 \\
(0.022)\end{array}$ \\
\hline $55-59$ & $\begin{array}{c}-0.01 \\
(0.018)\end{array}$ & $\begin{array}{c}0.05^{* * *} \\
(0.018)\end{array}$ & $\begin{array}{c}0.11^{* * *} \\
(0.024)\end{array}$ & $\begin{array}{c}0.15^{* * *} \\
(0.024)\end{array}$ & $\begin{array}{c}-0.06^{* * *} \\
(0.023)\end{array}$ & $\begin{array}{c}0.01 \\
(0.023)\end{array}$ \\
\hline $60-64$ & $\begin{array}{c}-0.01 \\
(0.019)\end{array}$ & $\begin{array}{c}0.07^{* * *} \\
(0.020)\end{array}$ & $\begin{array}{c}0.17^{* * *} \\
(0.025)\end{array}$ & $\begin{array}{c}0.22^{* * *} \\
(0.025)\end{array}$ & $\begin{array}{c}-0.09^{* * *} \\
(0.024)\end{array}$ & $\begin{array}{c}0.03 \\
(0.024)\end{array}$ \\
\hline $65-69$ & $\begin{array}{c}0.02 \\
(0.020)\end{array}$ & $\begin{array}{c}0.13^{* * *} \\
(0.021)\end{array}$ & $\begin{array}{c}0.32^{* * *} \\
(0.026)\end{array}$ & $\begin{array}{c}0.39^{* * *} \\
(0.026)\end{array}$ & $\begin{array}{c}-0.11^{* * *} \\
(0.026)\end{array}$ & $\begin{array}{c}0.04^{*} \\
(0.026)\end{array}$ \\
\hline $70-74$ & $\begin{array}{c}0.05^{* *} \\
(0.022)\end{array}$ & $\begin{array}{c}0.19^{* * *} \\
(0.022)\end{array}$ & $\begin{array}{c}0.37^{* * *} \\
(0.028)\end{array}$ & $\begin{array}{c}0.45^{* * *} \\
(0.028)\end{array}$ & $\begin{array}{c}-0.07^{* *} \\
(0.028)\end{array}$ & $\begin{array}{c}0.12^{* * *} \\
(0.028)\end{array}$ \\
\hline $75-79$ & $\begin{array}{c}0.12^{* * *} \\
(0.024)\end{array}$ & $\begin{array}{c}0.27^{* * *} \\
(0.024)\end{array}$ & $\begin{array}{c}0.53^{* * *} \\
(0.031)\end{array}$ & $\begin{array}{c}0.62^{* * *} \\
(0.031)\end{array}$ & $\begin{array}{c}-0.05^{*} \\
(0.030)\end{array}$ & $\begin{array}{c}0.17^{* * *} \\
(0.030)\end{array}$ \\
\hline $80-84$ & $\begin{array}{c}0.21^{* * *} \\
(0.027)\end{array}$ & $\begin{array}{c}0.39^{* * *} \\
(0.027)\end{array}$ & $\begin{array}{c}0.69^{* * *} \\
(0.034)\end{array}$ & $\begin{array}{c}0.80^{* * *} \\
(0.034)\end{array}$ & $\begin{array}{l}-0.02 \\
(0.035)\end{array}$ & $\begin{array}{c}0.23^{* * *} \\
(0.035)\end{array}$ \\
\hline Observations & 407 & 407 & 407 & 407 & 407 & 407 \\
\hline R-squared & 0.90 & 0.92 & 0.91 & 0.92 & 0.81 & 0.87 \\
\hline \multicolumn{7}{|c|}{ Cohorts effects } \\
\hline 1901 & $\begin{array}{c}-0.75^{* * *} \\
(0.077)\end{array}$ & $\begin{array}{c}-0.98^{* * *} \\
(0.078)\end{array}$ & $\begin{array}{c}-1.11^{* * *} \\
(0.098)\end{array}$ & $\begin{array}{c}-1.25^{* * *} \\
(0.098)\end{array}$ & $\begin{array}{c}-0.52^{* * *} \\
(0.099)\end{array}$ & $\begin{array}{c}-0.84^{* * *} \\
(0.099)\end{array}$ \\
\hline 1902 & $\begin{array}{c}-0.94^{* * *} \\
(0.076)\end{array}$ & $\begin{array}{c}-1.16^{* * *} \\
(0.077)\end{array}$ & $\begin{array}{c}-1.26^{* * *} \\
(0.094)\end{array}$ & $\begin{array}{c}-1.40^{* * *} \\
(0.094)\end{array}$ & $\begin{array}{c}-0.60^{* * *} \\
(0.104)\end{array}$ & $\begin{array}{c}-0.91^{\text {*** }} \\
(0.105)\end{array}$ \\
\hline 1903 & $\begin{array}{c}-0.91^{* * *} \\
(0.076)\end{array}$ & $\begin{array}{c}-1.13^{* * *} \\
(0.077)\end{array}$ & $\begin{array}{c}-1.25^{* * *} \\
(0.097)\end{array}$ & $\begin{array}{c}-1.39^{* * *} \\
(0.097)\end{array}$ & $\begin{array}{c}-0.72^{* * *} \\
(0.097)\end{array}$ & $\begin{array}{c}-1.02^{* * *} \\
(0.097)\end{array}$ \\
\hline 1904 & $\begin{array}{c}-0.86^{* * *} \\
(0.074)\end{array}$ & $\begin{array}{c}-1.09^{* * *} \\
(0.074)\end{array}$ & $\begin{array}{c}-1.11^{* * *} \\
(0.093)\end{array}$ & $\begin{array}{c}-1.26^{* * *} \\
(0.093)\end{array}$ & $\begin{array}{c}-0.71^{* * *} \\
(0.096)\end{array}$ & $\begin{array}{c}-1.02^{\text {*** }} \\
(0.096)\end{array}$ \\
\hline 1905 & $\begin{array}{c}-0.77^{* * *} \\
(0.065)\end{array}$ & $\begin{array}{c}-0.98^{* * *} \\
(0.065)\end{array}$ & $\begin{array}{c}-1.16^{* * *} \\
(0.082)\end{array}$ & $\begin{array}{c}-1.30^{* * *} \\
(0.082)\end{array}$ & $\begin{array}{c}-0.53^{* * *} \\
(0.084)\end{array}$ & $\begin{array}{c}-0.82^{* * *} \\
(0.084)\end{array}$ \\
\hline
\end{tabular}

Continued 


\begin{tabular}{|c|c|c|c|c|c|c|}
\hline \multirow[b]{2}{*}{ Variables } & \multicolumn{2}{|c|}{ Whole population } & \multicolumn{2}{|c|}{ Women } & \multicolumn{2}{|c|}{ Men } \\
\hline & M1 & M2 & M1 & M2 & M1 & M2 \\
\hline \multicolumn{7}{|c|}{ Cohorts effects } \\
\hline 1906 & $\begin{array}{c}-0.85^{* * *} \\
(0.063)\end{array}$ & $\begin{array}{c}-1.05^{* * *} \\
(0.063)\end{array}$ & $\begin{array}{c}-1.15^{* * *} \\
(0.079)\end{array}$ & $\begin{array}{c}-1.27^{* * *} \\
(0.079)\end{array}$ & $\begin{array}{c}-0.66^{\text {*** }} \\
(0.082)\end{array}$ & $\begin{array}{c}-0.94^{* * *} \\
(0.082)\end{array}$ \\
\hline 1907 & $\begin{array}{c}-0.80^{* * *} \\
(0.063)\end{array}$ & $\begin{array}{c}-1.00^{* * *} \\
(0.063)\end{array}$ & $\begin{array}{c}-1.11^{* * *} \\
(0.080)\end{array}$ & $\begin{array}{c}-1.24^{* * *} \\
(0.080)\end{array}$ & $\begin{array}{c}-0.64^{* * *} \\
(0.079)\end{array}$ & $\begin{array}{c}-0.92^{* * *} \\
(0.080)\end{array}$ \\
\hline 1908 & $\begin{array}{c}-0.76^{\text {*** }} \\
(0.061)\end{array}$ & $\begin{array}{c}-0.96^{* * *} \\
(0.061)\end{array}$ & $\begin{array}{c}-1.20^{* * *} \\
(0.077)\end{array}$ & $\begin{array}{c}-1.33^{* * *} \\
(0.077)\end{array}$ & $\begin{array}{c}-0.48^{* * *} \\
(0.078)\end{array}$ & $\begin{array}{r}-0.76^{\text {*** }} \\
(0.078)\end{array}$ \\
\hline 1909 & $\begin{array}{c}-0.82^{* * *} \\
(0.058)\end{array}$ & $\begin{array}{c}-1.02^{* * *} \\
(0.059)\end{array}$ & $\begin{array}{c}-1.15^{* * *} \\
(0.073)\end{array}$ & $\begin{array}{c}-1.28^{* * *} \\
(0.073)\end{array}$ & $\begin{array}{c}-0.58^{* * *} \\
(0.077)\end{array}$ & $\begin{array}{c}-0.86^{* * *} \\
(0.077)\end{array}$ \\
\hline 1910 & $\begin{array}{c}-0.75^{* * *} \\
(0.059)\end{array}$ & $\begin{array}{c}-0.93^{* * *} \\
(0.060)\end{array}$ & $\begin{array}{c}-1.11^{* * *} \\
(0.076)\end{array}$ & $\begin{array}{c}-1.23^{* * *} \\
(0.076)\end{array}$ & $\begin{array}{c}-0.55^{* * *} \\
(0.075)\end{array}$ & $\begin{array}{c}-0.80^{\text {*** }} \\
(0.075)\end{array}$ \\
\hline 1911 & $\begin{array}{c}-0.65^{* * *} \\
(0.055)\end{array}$ & $\begin{array}{c}-0.82^{* * *} \\
(0.055)\end{array}$ & $\begin{array}{c}-1.02^{* * *} \\
(0.070)\end{array}$ & $\begin{array}{c}-1.12^{* * *} \\
(0.070)\end{array}$ & $\begin{array}{c}-0.45^{* * *} \\
(0.069)\end{array}$ & $\begin{array}{c}-0.70^{* * *} \\
(0.069)\end{array}$ \\
\hline 1912 & $\begin{array}{c}-0.58^{* * *} \\
(0.053)\end{array}$ & $\begin{array}{c}-0.76^{* * *} \\
(0.054)\end{array}$ & $\begin{array}{c}-0.96^{* * *} \\
(0.068)\end{array}$ & $\begin{array}{c}-1.07^{* * *} \\
(0.068)\end{array}$ & $\begin{array}{c}-0.36^{* * *} \\
(0.068)\end{array}$ & $\begin{array}{c}-0.61^{* * *} \\
(0.068)\end{array}$ \\
\hline 1913 & $\begin{array}{c}-0.69^{* * *} \\
(0.052)\end{array}$ & $\begin{array}{c}-0.87^{* * *} \\
(0.053)\end{array}$ & $\begin{array}{c}-1.09^{* * *} \\
(0.067)\end{array}$ & $\begin{array}{c}-1.19^{* * *} \\
(0.067)\end{array}$ & $\begin{array}{c}-0.43^{* * *} \\
(0.067)\end{array}$ & $\begin{array}{c}-0.67^{* * *} \\
(0.067)\end{array}$ \\
\hline 1914 & $\begin{array}{c}-0.59^{* * *} \\
(0.053)\end{array}$ & $\begin{array}{c}-0.77^{* * *} \\
(0.053)\end{array}$ & $\begin{array}{c}-0.99^{* * *} \\
(0.068)\end{array}$ & $\begin{array}{c}-1.10^{* * *} \\
(0.068)\end{array}$ & $\begin{array}{c}-0.40^{* * *} \\
(0.066)\end{array}$ & $\begin{array}{r}-0.64^{* * *} \\
(0.066)\end{array}$ \\
\hline 1915 & $\begin{array}{c}-0.59^{* * *} \\
(0.052)\end{array}$ & $\begin{array}{c}-0.75^{* * *} \\
(0.052)\end{array}$ & $\begin{array}{c}-0.91^{* * *} \\
(0.066)\end{array}$ & $\begin{array}{c}-1.01^{* * *} \\
(0.066)\end{array}$ & $\begin{array}{c}-0.39^{* * *} \\
(0.066)\end{array}$ & $\begin{array}{r}-0.62^{* * *} \\
(0.066)\end{array}$ \\
\hline 1916 & $\begin{array}{c}-0.54^{* * *} \\
(0.054)\end{array}$ & $\begin{array}{c}-0.69^{* * *} \\
(0.054)\end{array}$ & $\begin{array}{c}-0.82^{* * *} \\
(0.068)\end{array}$ & $\begin{array}{c}-0.91^{* * *} \\
(0.068)\end{array}$ & $\begin{array}{c}-0.38^{* * *} \\
(0.069)\end{array}$ & $\begin{array}{c}-0.59^{* * *} \\
(0.069)\end{array}$ \\
\hline 1917 & $\begin{array}{c}-0.50^{* * *} \\
(0.053)\end{array}$ & $\begin{array}{c}-0.65^{* * *} \\
(0.053)\end{array}$ & $\begin{array}{c}-0.84^{* * *} \\
(0.069)\end{array}$ & $\begin{array}{c}-0.94^{* * *} \\
(0.069)\end{array}$ & $\begin{array}{c}-0.31^{* * *} \\
(0.067)\end{array}$ & $\begin{array}{c}-0.52^{* * *} \\
(0.067)\end{array}$ \\
\hline 1918 & $\begin{array}{c}-0.48^{* * *} \\
(0.052)\end{array}$ & $\begin{array}{c}-0.63^{* * *} \\
(0.052)\end{array}$ & $\begin{array}{c}-0.88^{* * *} \\
(0.067)\end{array}$ & $\begin{array}{c}-0.98^{* * *} \\
(0.067)\end{array}$ & $\begin{array}{c}-0.26^{* * *} \\
(0.065)\end{array}$ & $\begin{array}{c}-0.48^{* * *} \\
(0.065)\end{array}$ \\
\hline 1919 & $\begin{array}{c}-0.48^{* * *} \\
(0.049)\end{array}$ & $\begin{array}{c}-0.64^{* * *} \\
(0.050)\end{array}$ & $\begin{array}{c}-0.91^{* * *} \\
(0.064)\end{array}$ & $\begin{array}{c}-1.00^{* * *} \\
(0.064)\end{array}$ & $\begin{array}{c}-0.25^{* * *} \\
(0.062)\end{array}$ & $\begin{array}{c}-0.47^{* * *} \\
(0.062)\end{array}$ \\
\hline 1920 & $\begin{array}{c}-0.44^{* * *} \\
(0.047)\end{array}$ & $\begin{array}{c}-0.58^{* * *} \\
(0.047)\end{array}$ & $\begin{array}{c}-0.83^{* * *} \\
(0.060)\end{array}$ & $\begin{array}{c}-0.91^{* * *} \\
(0.060)\end{array}$ & $\begin{array}{c}-0.24^{* * *} \\
(0.059)\end{array}$ & $\begin{array}{c}-0.44^{* * *} \\
(0.059)\end{array}$ \\
\hline 1921 & $\begin{array}{c}-0.49^{* * *} \\
(0.044)\end{array}$ & $\begin{array}{c}-0.62^{* * *} \\
(0.044)\end{array}$ & $\begin{array}{c}-0.83^{* * *} \\
(0.056)\end{array}$ & $\begin{array}{c}-0.91^{* * *} \\
(0.056)\end{array}$ & $\begin{array}{c}-0.28^{* * *} \\
(0.055)\end{array}$ & $\begin{array}{r}-0.46^{* * *} \\
(0.055)\end{array}$ \\
\hline 1922 & $\begin{array}{c}-0.48^{* * *} \\
(0.043)\end{array}$ & $\begin{array}{c}-0.61^{* * *} \\
(0.043)\end{array}$ & $\begin{array}{c}-0.83^{* * *} \\
(0.056)\end{array}$ & $\begin{array}{c}-0.91^{* * *} \\
(0.056)\end{array}$ & $\begin{array}{c}-0.31^{* * *} \\
(0.054)\end{array}$ & $\begin{array}{r}-0.49^{* * *} \\
(0.054)\end{array}$ \\
\hline 1923 & $\begin{array}{c}-0.43^{* * *} \\
(0.043)\end{array}$ & $\begin{array}{c}-0.56^{* * *} \\
(0.043)\end{array}$ & $\begin{array}{c}-0.80^{* * *} \\
(0.056)\end{array}$ & $\begin{array}{c}-0.88^{* * *} \\
(0.056)\end{array}$ & $\begin{array}{c}-0.22^{* * *} \\
(0.054)\end{array}$ & $\begin{array}{c}-0.40^{\text {*** }} \\
(0.054)\end{array}$ \\
\hline 1924 & $\begin{array}{c}-0.43^{* * *} \\
(0.043)\end{array}$ & $\begin{array}{c}-0.56^{* * *} \\
(0.043)\end{array}$ & $\begin{array}{c}-0.81^{* * *} \\
(0.056)\end{array}$ & $\begin{array}{c}-0.89^{* * *} \\
(0.056)\end{array}$ & $\begin{array}{c}-0.23^{* * *} \\
(0.054)\end{array}$ & $\begin{array}{c}-0.41^{* * *} \\
(0.054)\end{array}$ \\
\hline
\end{tabular}




\begin{tabular}{|c|c|c|c|c|c|c|}
\hline \multirow[b]{2}{*}{ Variables } & \multicolumn{2}{|c|}{ Whole population } & \multicolumn{2}{|c|}{ Women } & \multicolumn{2}{|c|}{ Men } \\
\hline & M1 & M2 & M1 & M2 & M1 & M2 \\
\hline \multicolumn{7}{|c|}{ Cohorts effects } \\
\hline 1925 & $\begin{array}{c}-0.45^{* * *} \\
(0.043)\end{array}$ & $\begin{array}{c}-0.57^{* * *} \\
(0.043)\end{array}$ & $\begin{array}{c}-0.82^{* * *} \\
(0.056)\end{array}$ & $\begin{array}{c}-0.88^{* * *} \\
(0.056)\end{array}$ & $\begin{array}{c}-0.25^{* * *} \\
(0.054)\end{array}$ & $\begin{array}{r}-0.42^{* * *} \\
(0.055)\end{array}$ \\
\hline 1926 & $\begin{array}{c}-0.41^{* * *} \\
(0.042)\end{array}$ & $\begin{array}{c}-0.51^{* * *} \\
(0.042)\end{array}$ & $\begin{array}{c}-0.78^{* * *} \\
(0.054)\end{array}$ & $\begin{array}{c}-0.84^{* * *} \\
(0.054)\end{array}$ & $\begin{array}{c}-0.23^{* * *} \\
(0.052)\end{array}$ & $\begin{array}{c}-0.37^{* * *} \\
(0.052)\end{array}$ \\
\hline 1927 & $\begin{array}{c}-0.39^{* * *} \\
(0.041)\end{array}$ & $\begin{array}{c}-0.49^{* * *} \\
(0.041)\end{array}$ & $\begin{array}{c}-0.66^{* * *} \\
(0.053)\end{array}$ & $\begin{array}{c}-0.73^{* * *} \\
(0.053)\end{array}$ & $\begin{array}{c}-0.24^{* * *} \\
(0.051)\end{array}$ & $\begin{array}{c}-0.38^{\text {*** }} \\
(0.051)\end{array}$ \\
\hline 1928 & $\begin{array}{c}-0.41^{* * *} \\
(0.041)\end{array}$ & $\begin{array}{c}-0.52^{* * *} \\
(0.041)\end{array}$ & $\begin{array}{c}-0.77^{* * *} \\
(0.053)\end{array}$ & $\begin{array}{c}-0.83^{* * *} \\
(0.053)\end{array}$ & $\begin{array}{c}-0.21^{* * *} \\
(0.051)\end{array}$ & $\begin{array}{c}-0.35^{\text {*** }} \\
(0.052)\end{array}$ \\
\hline 1929 & $\begin{array}{c}-0.39^{* * *} \\
(0.041)\end{array}$ & $\begin{array}{c}-0.49^{* * *} \\
(0.041)\end{array}$ & $\begin{array}{c}-0.73^{* * *} \\
(0.053)\end{array}$ & $\begin{array}{c}-0.79^{* * *} \\
(0.053)\end{array}$ & $\begin{array}{c}-0.18^{* * *} \\
(0.051)\end{array}$ & $\begin{array}{c}-0.32^{\text {*** }} \\
(0.051)\end{array}$ \\
\hline 1930 & $\begin{array}{c}-0.41^{* * *} \\
(0.041)\end{array}$ & $\begin{array}{c}-0.50^{* * *} \\
(0.041)\end{array}$ & $\begin{array}{c}-0.71^{* * *} \\
(0.053)\end{array}$ & $\begin{array}{c}-0.77^{* * *} \\
(0.053)\end{array}$ & $\begin{array}{c}-0.23^{* * *} \\
(0.051)\end{array}$ & $\begin{array}{c}-0.35^{* * *} \\
(0.051)\end{array}$ \\
\hline 1931 & $\begin{array}{c}-0.36^{* * *} \\
(0.040)\end{array}$ & $\begin{array}{c}-0.44^{* * *} \\
(0.040)\end{array}$ & $\begin{array}{c}-0.66^{* * *} \\
(0.052)\end{array}$ & $\begin{array}{c}-0.70^{* * *} \\
(0.052)\end{array}$ & $\begin{array}{c}-0.21^{* * *} \\
(0.050)\end{array}$ & $\begin{array}{c}-0.31^{\text {*** }} \\
(0.050)\end{array}$ \\
\hline 1932 & $\begin{array}{c}-0.32^{* * *} \\
(0.040)\end{array}$ & $\begin{array}{c}-0.40^{* * *} \\
(0.040)\end{array}$ & $\begin{array}{c}-0.56^{* * *} \\
(0.052)\end{array}$ & $\begin{array}{c}-0.61^{* * *} \\
(0.052)\end{array}$ & $\begin{array}{c}-0.19^{* * *} \\
(0.050)\end{array}$ & $\begin{array}{c}-0.30^{\text {*** }} \\
(0.050)\end{array}$ \\
\hline 1933 & $\begin{array}{c}-0.37^{* * *} \\
(0.040)\end{array}$ & $\begin{array}{c}-0.45^{* * *} \\
(0.040)\end{array}$ & $\begin{array}{c}-0.65^{* * *} \\
(0.052)\end{array}$ & $\begin{array}{c}-0.70^{* * *} \\
(0.052)\end{array}$ & $\begin{array}{c}-0.21^{* * *} \\
(0.050)\end{array}$ & $\begin{array}{c}-0.32^{\text {*** }} \\
(0.050)\end{array}$ \\
\hline 1934 & $\begin{array}{c}-0.33^{* * *} \\
(0.040)\end{array}$ & $\begin{array}{c}-0.41^{* * *} \\
(0.040)\end{array}$ & $\begin{array}{c}-0.60^{* * *} \\
(0.052)\end{array}$ & $\begin{array}{c}-0.65^{* * *} \\
(0.052)\end{array}$ & $\begin{array}{c}-0.18^{* * *} \\
(0.050)\end{array}$ & $\begin{array}{c}-0.29^{* * *} \\
(0.050)\end{array}$ \\
\hline 1935 & $\begin{array}{c}-0.28^{* * *} \\
(0.040)\end{array}$ & $\begin{array}{c}-0.35^{* * *} \\
(0.040)\end{array}$ & $\begin{array}{c}-0.54^{* * *} \\
(0.052)\end{array}$ & $\begin{array}{c}-0.58^{* * *} \\
(0.052)\end{array}$ & $\begin{array}{c}-0.16^{* * *} \\
(0.050)\end{array}$ & $\begin{array}{c}-0.25^{\text {*** }} \\
(0.050)\end{array}$ \\
\hline 1936 & $\begin{array}{c}-0.26^{* * *} \\
(0.040)\end{array}$ & $\begin{array}{c}-0.31^{\text {*** }} \\
(0.040)\end{array}$ & $\begin{array}{c}-0.51^{* * *} \\
(0.052)\end{array}$ & $\begin{array}{c}-0.54^{* * *} \\
(0.052)\end{array}$ & $\begin{array}{c}-0.11^{* *} \\
(0.050)\end{array}$ & $\begin{array}{c}-0.19^{\text {*** }} \\
(0.050)\end{array}$ \\
\hline 1937 & $\begin{array}{c}-0.23^{* * *} \\
(0.040)\end{array}$ & $\begin{array}{c}-0.28^{* * *} \\
(0.040)\end{array}$ & $\begin{array}{c}-0.42^{* * *} \\
(0.052)\end{array}$ & $\begin{array}{c}-0.45^{* * *} \\
(0.052)\end{array}$ & $\begin{array}{c}-0.13^{* * *} \\
(0.050)\end{array}$ & $\begin{array}{c}-0.20^{\text {*** }} \\
(0.050)\end{array}$ \\
\hline 1938 & $\begin{array}{c}-0.22^{* * *} \\
(0.040)\end{array}$ & $\begin{array}{c}-0.27^{* * *} \\
(0.040)\end{array}$ & $\begin{array}{c}-0.44^{* * *} \\
(0.052)\end{array}$ & $\begin{array}{c}-0.47^{* * *} \\
(0.052)\end{array}$ & $\begin{array}{c}-0.08 \\
(0.050)\end{array}$ & $\begin{array}{c}-0.15^{* * *} \\
(0.050)\end{array}$ \\
\hline 1939 & $\begin{array}{c}-0.18^{* * *} \\
(0.040)\end{array}$ & $\begin{array}{c}-0.23^{* * *} \\
(0.040)\end{array}$ & $\begin{array}{c}-0.38^{* * *} \\
(0.052)\end{array}$ & $\begin{array}{c}-0.41^{* * *} \\
(0.052)\end{array}$ & $\begin{array}{c}-0.08^{*} \\
(0.049)\end{array}$ & $\begin{array}{c}-0.16^{\text {*** }} \\
(0.050)\end{array}$ \\
\hline 1940 & $\begin{array}{c}-0.16^{* * *} \\
(0.040)\end{array}$ & $\begin{array}{c}-0.20^{* * *} \\
(0.040)\end{array}$ & $\begin{array}{c}-0.37^{* * *} \\
(0.052)\end{array}$ & $\begin{array}{c}-0.39^{* * *} \\
(0.052)\end{array}$ & $\begin{array}{l}-0.04 \\
(0.050)\end{array}$ & $\begin{array}{c}-0.10^{* *} \\
(0.050)\end{array}$ \\
\hline 1941 & $\begin{array}{c}-0.15^{* * *} \\
(0.040)\end{array}$ & $\begin{array}{c}-0.18^{* * *} \\
(0.040)\end{array}$ & $\begin{array}{c}-0.37^{* * *} \\
(0.052)\end{array}$ & $\begin{array}{c}-0.38^{* * * *} \\
(0.052)\end{array}$ & $\begin{array}{l}-0.02 \\
(0.050)\end{array}$ & $\begin{array}{l}-0.06 \\
(0.050)\end{array}$ \\
\hline 1942 & $\begin{array}{c}-0.13^{* * *} \\
(0.040)\end{array}$ & $\begin{array}{c}-0.15^{* * *} \\
(0.040)\end{array}$ & $\begin{array}{c}-0.21^{* * *} \\
(0.052)\end{array}$ & $\begin{array}{c}-0.22^{* * *} \\
(0.052)\end{array}$ & $\begin{array}{l}-0.07 \\
(0.050)\end{array}$ & $\begin{array}{r}-0.11^{* *} \\
(0.050)\end{array}$ \\
\hline 1943 & $\begin{array}{r}-0.08^{* *} \\
(0.039)\end{array}$ & $\begin{array}{c}-0.10^{* * *} \\
(0.040)\end{array}$ & $\begin{array}{c}-0.21^{* * *} \\
(0.052)\end{array}$ & $\begin{array}{c}-0.23^{* * *} \\
(0.052)\end{array}$ & $\begin{array}{l}-0.02 \\
(0.049)\end{array}$ & $\begin{array}{l}-0.06 \\
(0.049)\end{array}$ \\
\hline
\end{tabular}




\begin{tabular}{|c|c|c|c|c|c|c|}
\hline \multirow[b]{2}{*}{ Variables } & \multicolumn{2}{|c|}{ Whole population } & \multicolumn{2}{|c|}{ Women } & \multicolumn{2}{|c|}{ Men } \\
\hline & M1 & M2 & M1 & M2 & M1 & M2 \\
\hline \multicolumn{7}{|c|}{ Cohorts effects } \\
\hline 1944 & $\begin{array}{c}-0.09^{* *} \\
(0.039)\end{array}$ & $\begin{array}{c}-0.12^{* * *} \\
(0.039)\end{array}$ & $\begin{array}{c}-0.19^{* * *} \\
(0.051)\end{array}$ & $\begin{array}{c}-0.21^{* * *} \\
(0.051)\end{array}$ & $\begin{array}{c}-0.03 \\
(0.048)\end{array}$ & $\begin{array}{c}-0.07 \\
(0.049)\end{array}$ \\
\hline 1945 & $\begin{array}{c}-0.09^{* *} \\
(0.039)\end{array}$ & $\begin{array}{c}-0.10^{* *} \\
(0.039)\end{array}$ & $\begin{array}{c}-0.19^{* * *} \\
(0.051)\end{array}$ & $\begin{array}{c}-0.20^{* * *} \\
(0.051)\end{array}$ & $\begin{array}{c}-0.02 \\
(0.049)\end{array}$ & $\begin{array}{c}-0.04 \\
(0.049)\end{array}$ \\
\hline 1946 & Ref & Ref & Ref & Ref & Ref & Ref \\
\hline 1947 & $\begin{array}{c}-0.04 \\
(0.037)\end{array}$ & $\begin{array}{c}-0.03 \\
(0.038)\end{array}$ & $\begin{array}{c}-0.06 \\
(0.049)\end{array}$ & $\begin{array}{c}-0.06 \\
(0.049)\end{array}$ & $\begin{array}{l}-0.01 \\
(0.046)\end{array}$ & $\begin{array}{c}-0.01 \\
(0.046)\end{array}$ \\
\hline 1948 & $\begin{array}{c}-0.01 \\
(0.037)\end{array}$ & $\begin{array}{c}-0.00 \\
(0.038)\end{array}$ & $\begin{array}{c}-0.02 \\
(0.049)\end{array}$ & $\begin{array}{c}-0.02 \\
(0.049)\end{array}$ & $\begin{array}{c}0.01 \\
(0.046)\end{array}$ & $\begin{array}{c}0.01 \\
(0.046)\end{array}$ \\
\hline 1949 & $\begin{array}{l}-0.04 \\
(0.037)\end{array}$ & $\begin{array}{c}-0.04 \\
(0.038)\end{array}$ & $\begin{array}{c}-0.06 \\
(0.049)\end{array}$ & $\begin{array}{c}-0.06 \\
(0.049)\end{array}$ & $\begin{array}{c}-0.01 \\
(0.046)\end{array}$ & $\begin{array}{c}-0.01 \\
(0.047)\end{array}$ \\
\hline 1950 & $\begin{array}{c}-0.01 \\
(0.038)\end{array}$ & $\begin{array}{l}-0.00 \\
(0.038)\end{array}$ & $\begin{array}{c}-0.01 \\
(0.049)\end{array}$ & $\begin{array}{c}-0.01 \\
(0.049)\end{array}$ & $\begin{array}{c}-0.01 \\
(0.047)\end{array}$ & $\begin{array}{c}0.01 \\
(0.047)\end{array}$ \\
\hline 1951 & $\begin{array}{c}-0.03 \\
(0.038)\end{array}$ & $\begin{array}{c}0.00 \\
(0.038)\end{array}$ & $\begin{array}{c}0.04 \\
(0.049)\end{array}$ & $\begin{array}{c}0.06 \\
(0.049)\end{array}$ & $\begin{array}{l}-0.04 \\
(0.047)\end{array}$ & $\begin{array}{c}0.00 \\
(0.047)\end{array}$ \\
\hline 1952 & $\begin{array}{c}-0.03 \\
(0.038)\end{array}$ & $\begin{array}{c}-0.00 \\
(0.038)\end{array}$ & $\begin{array}{c}0.04 \\
(0.049)\end{array}$ & $\begin{array}{c}0.06 \\
(0.049)\end{array}$ & $\begin{array}{c}-0.06 \\
(0.047)\end{array}$ & $\begin{array}{l}-0.02 \\
(0.047)\end{array}$ \\
\hline 1953 & $\begin{array}{c}-0.03 \\
(0.038)\end{array}$ & $\begin{array}{c}0.00 \\
(0.038)\end{array}$ & $\begin{array}{c}0.06 \\
(0.049)\end{array}$ & $\begin{array}{c}0.07 \\
(0.049)\end{array}$ & $\begin{array}{l}-0.05 \\
(0.047)\end{array}$ & $\begin{array}{c}-0.01 \\
(0.047)\end{array}$ \\
\hline 1954 & $\begin{array}{c}-0.03 \\
(0.037)\end{array}$ & $\begin{array}{c}-0.00 \\
(0.038)\end{array}$ & $\begin{array}{c}0.01 \\
(0.049)\end{array}$ & $\begin{array}{c}0.03 \\
(0.049)\end{array}$ & $\begin{array}{c}-0.03 \\
(0.047)\end{array}$ & $\begin{array}{c}0.01 \\
(0.047)\end{array}$ \\
\hline 1955 & $\begin{array}{l}-0.04 \\
(0.039)\end{array}$ & $\begin{array}{l}-0.00 \\
(0.040)\end{array}$ & $\begin{array}{c}0.01 \\
(0.051)\end{array}$ & $\begin{array}{c}0.04 \\
(0.051)\end{array}$ & $\begin{array}{c}-0.06 \\
(0.049)\end{array}$ & $\begin{array}{c}-0.01 \\
(0.049)\end{array}$ \\
\hline 1956 & $\begin{array}{c}-0.00 \\
(0.039)\end{array}$ & $\begin{array}{c}0.05 \\
(0.039)\end{array}$ & $\begin{array}{c}0.06 \\
(0.051)\end{array}$ & $\begin{array}{c}0.10^{*} \\
(0.051)\end{array}$ & $\begin{array}{c}-0.02 \\
(0.049)\end{array}$ & $\begin{array}{c}0.06 \\
(0.049)\end{array}$ \\
\hline 1957 & $\begin{array}{c}0.02 \\
(0.039)\end{array}$ & $\begin{array}{c}0.07^{*} \\
(0.039)\end{array}$ & $\begin{array}{c}0.07 \\
(0.051)\end{array}$ & $\begin{array}{c}0.10^{* *} \\
(0.051)\end{array}$ & $\begin{array}{c}0.01 \\
(0.049)\end{array}$ & $\begin{array}{c}0.08^{*} \\
(0.049)\end{array}$ \\
\hline 1958 & $\begin{array}{c}0.05 \\
(0.039)\end{array}$ & $\begin{array}{c}0.11^{* * *} \\
(0.040)\end{array}$ & $\begin{array}{c}0.14^{* * *} \\
(0.051)\end{array}$ & $\begin{array}{c}0.17^{* * *} \\
(0.051)\end{array}$ & $\begin{array}{c}0.03 \\
(0.049)\end{array}$ & $\begin{array}{c}0.10^{* *} \\
(0.049)\end{array}$ \\
\hline 1959 & $\begin{array}{c}-0.00 \\
(0.039)\end{array}$ & $\begin{array}{c}0.05 \\
(0.039)\end{array}$ & $\begin{array}{c}0.07 \\
(0.051)\end{array}$ & $\begin{array}{c}0.11^{* *} \\
(0.051)\end{array}$ & $\begin{array}{c}-0.02 \\
(0.049)\end{array}$ & $\begin{array}{c}0.06 \\
(0.049)\end{array}$ \\
\hline 1960 & $\begin{array}{c}0.00 \\
(0.040)\end{array}$ & $\begin{array}{c}0.07^{*} \\
(0.040)\end{array}$ & $\begin{array}{c}0.08 \\
(0.052)\end{array}$ & $\begin{array}{c}0.12^{* *} \\
(0.052)\end{array}$ & $\begin{array}{c}-0.01 \\
(0.050)\end{array}$ & $\begin{array}{c}0.08 \\
(0.050)\end{array}$ \\
\hline 1961 & $\begin{array}{c}0.04 \\
(0.042)\end{array}$ & $\begin{array}{c}0.12^{* * *} \\
(0.042)\end{array}$ & $\begin{array}{c}0.08 \\
(0.054)\end{array}$ & $\begin{array}{c}0.13^{* *} \\
(0.054)\end{array}$ & $\begin{array}{c}0.06 \\
(0.052)\end{array}$ & $\begin{array}{c}0.17^{\text {*** }} \\
(0.053)\end{array}$ \\
\hline 1962 & $\begin{array}{c}0.02 \\
(0.042)\end{array}$ & $\begin{array}{c}0.11^{* *} \\
(0.042)\end{array}$ & $\begin{array}{c}0.13^{* *} \\
(0.054)\end{array}$ & $\begin{array}{c}0.19^{* * *} \\
(0.054)\end{array}$ & $\begin{array}{l}-0.02 \\
(0.052)\end{array}$ & $\begin{array}{c}0.09^{*} \\
(0.052)\end{array}$ \\
\hline
\end{tabular}

Continued 


\begin{tabular}{|c|c|c|c|c|c|c|}
\hline \multirow[b]{2}{*}{ Variables } & \multicolumn{2}{|c|}{ Whole population } & \multicolumn{2}{|c|}{ Women } & \multicolumn{2}{|c|}{ Men } \\
\hline & M1 & M2 & M1 & M2 & M1 & M2 \\
\hline \multicolumn{7}{|c|}{ Cohorts effects } \\
\hline 1963 & $\begin{array}{c}0.04 \\
(0.042)\end{array}$ & $\begin{array}{c}0.12^{\text {*** }} \\
(0.042)\end{array}$ & $\begin{array}{c}0.18^{* * *} \\
(0.055)\end{array}$ & $\begin{array}{c}0.23^{* * *} \\
(0.055)\end{array}$ & $\begin{array}{l}-0.04 \\
(0.052)\end{array}$ & $\begin{array}{c}0.07 \\
(0.052)\end{array}$ \\
\hline 1964 & $\begin{array}{c}-0.01 \\
(0.042)\end{array}$ & $\begin{array}{c}0.07^{*} \\
(0.042)\end{array}$ & $\begin{array}{c}0.15^{* * *} \\
(0.055)\end{array}$ & $\begin{array}{c}0.20^{* * *} \\
(0.055)\end{array}$ & $\begin{array}{c}-0.09^{*} \\
(0.052)\end{array}$ & $\begin{array}{c}0.02 \\
(0.052)\end{array}$ \\
\hline 1965 & $\begin{array}{c}0.02 \\
(0.045)\end{array}$ & $\begin{array}{c}0.11^{* *} \\
(0.045)\end{array}$ & $\begin{array}{c}0.14^{* *} \\
(0.058)\end{array}$ & $\begin{array}{c}0.19^{* * *} \\
(0.058)\end{array}$ & $\begin{array}{l}-0.03 \\
(0.056)\end{array}$ & $\begin{array}{c}0.10^{*} \\
(0.056)\end{array}$ \\
\hline 1966 & $\begin{array}{c}0.11^{* *} \\
(0.045)\end{array}$ & $\begin{array}{c}0.22^{* * *} \\
(0.045)\end{array}$ & $\begin{array}{c}0.21^{* * *} \\
(0.059)\end{array}$ & $\begin{array}{c}0.28^{* * *} \\
(0.059)\end{array}$ & $\begin{array}{c}0.08 \\
(0.056)\end{array}$ & $\begin{array}{c}0.23^{* * *} \\
(0.056)\end{array}$ \\
\hline 1967 & $\begin{array}{c}0.08^{*} \\
(0.045)\end{array}$ & $\begin{array}{c}0.19^{* * *} \\
(0.046)\end{array}$ & $\begin{array}{c}0.30^{* * *} \\
(0.059)\end{array}$ & $\begin{array}{c}0.36^{* * *} \\
(0.059)\end{array}$ & $\begin{array}{l}-0.03 \\
(0.057)\end{array}$ & $\begin{array}{c}0.12^{* *} \\
(0.057)\end{array}$ \\
\hline 1968 & $\begin{array}{c}0.03 \\
(0.046)\end{array}$ & $\begin{array}{c}0.14^{* * *} \\
(0.046)\end{array}$ & $\begin{array}{c}0.18^{* * *} \\
(0.059)\end{array}$ & $\begin{array}{c}0.25^{* * *} \\
(0.059)\end{array}$ & $\begin{array}{l}-0.03 \\
(0.057)\end{array}$ & $\begin{array}{c}0.12^{* *} \\
(0.057)\end{array}$ \\
\hline 1969 & $\begin{array}{c}0.02 \\
(0.045)\end{array}$ & $\begin{array}{c}0.13^{* * *} \\
(0.046)\end{array}$ & $\begin{array}{c}0.18^{* * *} \\
(0.059)\end{array}$ & $\begin{array}{c}0.25^{* * *} \\
(0.059)\end{array}$ & $\begin{array}{l}-0.05 \\
(0.057)\end{array}$ & $\begin{array}{c}0.10^{*} \\
(0.057)\end{array}$ \\
\hline 1970 & $\begin{array}{c}0.06 \\
(0.046)\end{array}$ & $\begin{array}{c}0.18^{* * *} \\
(0.047)\end{array}$ & $\begin{array}{c}0.27^{* * *} \\
(0.060)\end{array}$ & $\begin{array}{c}0.34^{* * *} \\
(0.060)\end{array}$ & $\begin{array}{l}-0.05 \\
(0.058)\end{array}$ & $\begin{array}{c}0.11^{*} \\
(0.058)\end{array}$ \\
\hline 1971 & $\begin{array}{c}0.13^{* *} \\
(0.050)\end{array}$ & $\begin{array}{c}0.26^{* * *} \\
(0.050)\end{array}$ & $\begin{array}{c}0.33^{* * *} \\
(0.065)\end{array}$ & $\begin{array}{c}0.42^{* * *} \\
(0.065)\end{array}$ & $\begin{array}{c}0.02 \\
(0.062)\end{array}$ & $\begin{array}{c}0.20^{* * *} \\
(0.062)\end{array}$ \\
\hline 1972 & $\begin{array}{c}0.14^{* * *} \\
(0.050)\end{array}$ & $\begin{array}{c}0.28^{* * *} \\
(0.050)\end{array}$ & $\begin{array}{c}0.37^{* * *} \\
(0.065)\end{array}$ & $\begin{array}{c}0.45^{* * *} \\
(0.065)\end{array}$ & $\begin{array}{c}0.02 \\
(0.063)\end{array}$ & $\begin{array}{c}0.21^{* * *} \\
(0.063)\end{array}$ \\
\hline 1973 & $\begin{array}{l}0.06 \\
(0.051)\end{array}$ & $\begin{array}{c}0.20^{* * *} \\
(0.051)\end{array}$ & $\begin{array}{c}0.26^{* * *} \\
(0.065)\end{array}$ & $\begin{array}{c}0.34^{* * *} \\
(0.065)\end{array}$ & $\begin{array}{l}-0.03 \\
(0.064)\end{array}$ & $\begin{array}{c}0.16^{* *} \\
(0.064)\end{array}$ \\
\hline 1974 & $\begin{array}{l}0.04 \\
(0.051)\end{array}$ & $\begin{array}{c}0.17^{\text {*** }} \\
(0.051)\end{array}$ & $\begin{array}{c}0.32^{* * * *} \\
(0.066)\end{array}$ & $\begin{array}{c}0.41^{* * *} \\
(0.066)\end{array}$ & $\begin{array}{c}-0.13^{* *} \\
(0.064)\end{array}$ & $\begin{array}{c}0.06 \\
(0.064)\end{array}$ \\
\hline 1975 & $\begin{array}{c}0.13^{* *} \\
(0.060)\end{array}$ & $\begin{array}{c}0.27^{* * *} \\
(0.060)\end{array}$ & $\begin{array}{c}0.41^{* * *} \\
(0.077)\end{array}$ & $\begin{array}{c}0.50^{* * *} \\
(0.078)\end{array}$ & $\begin{array}{l}-0.03 \\
(0.074)\end{array}$ & $\begin{array}{c}0.16^{* *} \\
(0.075)\end{array}$ \\
\hline 1976 & $\begin{array}{c}0.19^{* * *} \\
(0.061)\end{array}$ & $\begin{array}{c}0.35^{\text {*** }} \\
(0.061)\end{array}$ & $\begin{array}{c}0.41^{* * *} \\
(0.079)\end{array}$ & $\begin{array}{c}0.51^{\text {*** }} \\
(0.079)\end{array}$ & $\begin{array}{c}0.08 \\
(0.075)\end{array}$ & $\begin{array}{c}0.30^{* * *} \\
(0.076)\end{array}$ \\
\hline 1977 & $\begin{array}{c}0.28^{* * *} \\
(0.061)\end{array}$ & $\begin{array}{c}0.44^{* * *} \\
(0.062)\end{array}$ & $\begin{array}{c}0.55^{\text {*** }} \\
(0.079)\end{array}$ & $\begin{array}{c}0.65^{\text {*** }} \\
(0.079)\end{array}$ & $\begin{array}{c}0.12 \\
(0.076)\end{array}$ & $\begin{array}{c}0.34^{* * *} \\
(0.077)\end{array}$ \\
\hline 1978 & $\begin{array}{c}0.18^{* * *} \\
(0.061)\end{array}$ & $\begin{array}{c}0.35^{* * *} \\
(0.061)\end{array}$ & $\begin{array}{c}0.42^{* * *} \\
(0.079)\end{array}$ & $\begin{array}{c}0.52^{* * *} \\
(0.079)\end{array}$ & $\begin{array}{c}0.06 \\
(0.076)\end{array}$ & $\begin{array}{c}0.28^{* * *} \\
(0.076)\end{array}$ \\
\hline 1979 & $\begin{array}{c}0.11^{*} \\
(0.061)\end{array}$ & $\begin{array}{c}0.27^{* * *} \\
(0.062)\end{array}$ & $\begin{array}{c}0.31^{* * *} \\
(0.079)\end{array}$ & $\begin{array}{c}0.41^{\text {*** }} \\
(0.079)\end{array}$ & $\begin{array}{c}0.04 \\
(0.078)\end{array}$ & $\begin{array}{c}0.26^{* * *} \\
(0.078)\end{array}$ \\
\hline Constant & $\begin{array}{c}10.29^{* * *} \\
(0.029)\end{array}$ & $\begin{array}{l}10.21^{\text {*** }} \\
(0.030)\end{array}$ & $\begin{array}{c}9.98^{* * *} \\
(0.038)\end{array}$ & $\begin{array}{c}9.93^{* * *} \\
(0.038)\end{array}$ & $\begin{array}{c}10.50^{* * *} \\
(0.037)\end{array}$ & $\begin{array}{c}10.39^{* * *} \\
(0.037)\end{array}$ \\
\hline Observations & 407 & 407 & 407 & 407 & 407 & 407 \\
\hline R-squared & 0.90 & 0.92 & 0.91 & 0.92 & 0.81 & 0.87 \\
\hline
\end{tabular}

Continued 


\begin{tabular}{|c|c|c|c|c|c|c|}
\hline \multirow[b]{2}{*}{ Variables } & \multicolumn{2}{|c|}{ Whole population } & \multicolumn{2}{|c|}{ Women } & \multicolumn{2}{|c|}{ Men } \\
\hline & M1 & M2 & M1 & M2 & M1 & M2 \\
\hline \multicolumn{7}{|c|}{ Period effects } \\
\hline 1979 & Omm & $\mathrm{Omm}$ & Omm & Omm & Omm & Omm \\
\hline 1984 & $\mathrm{Omm}$ & Omm & Omm & Omm & $\mathrm{Omm}$ & Omm \\
\hline 1989 & $\begin{array}{c}-0.01 \\
(0.009)\end{array}$ & $\begin{array}{c}-0.01 \\
(0.009)\end{array}$ & $\begin{array}{c}0.06^{* * *} \\
(0.012)\end{array}$ & $\begin{array}{c}0.06^{* * *} \\
(0.012)\end{array}$ & $\begin{array}{c}-0.05^{\text {*** }} \\
(0.012)\end{array}$ & $\begin{array}{c}-0.05^{* * *} \\
(0.012)\end{array}$ \\
\hline 1995 & $\begin{array}{c}-0.03^{* * *} \\
(0.009)\end{array}$ & $\begin{array}{c}-0.03^{* * *} \\
(0.010)\end{array}$ & $\begin{array}{l}-0.02 \\
(0.012)\end{array}$ & $\begin{array}{l}-0.02 \\
(0.012)\end{array}$ & $\begin{array}{l}-0.02 \\
(0.012)\end{array}$ & $\begin{array}{r}-0.03^{* *} \\
(0.012)\end{array}$ \\
\hline 2000 & $\begin{array}{c}-0.00 \\
(0.009)\end{array}$ & $\begin{array}{c}0.00 \\
(0.009)\end{array}$ & $\begin{array}{c}0.02^{*} \\
(0.012)\end{array}$ & $\begin{array}{c}0.03^{* *} \\
(0.012)\end{array}$ & $\begin{array}{l}-0.02 \\
(0.011)\end{array}$ & $\begin{array}{l}-0.01 \\
(0.011)\end{array}$ \\
\hline 2005 & $\begin{array}{c}0.06^{* * *} \\
(0.009)\end{array}$ & $\begin{array}{c}0.06^{* * *} \\
(0.009)\end{array}$ & $\begin{array}{c}0.05^{* * *} \\
(0.011)\end{array}$ & $\begin{array}{c}0.05^{* * *} \\
(0.011)\end{array}$ & $\begin{array}{c}0.06^{* * *} \\
(0.011)\end{array}$ & $\begin{array}{c}0.07^{* * *} \\
(0.011)\end{array}$ \\
\hline 2010 & $\begin{array}{c}-0.02^{* * *} \\
(0.008)\end{array}$ & $\begin{array}{c}-0.03^{* * *} \\
(0.008)\end{array}$ & $\begin{array}{c}-0.07^{* * *} \\
(0.010)\end{array}$ & $\begin{array}{c}-0.07^{* * *} \\
(0.010)\end{array}$ & $\begin{array}{c}-0.01 \\
(0.010)\end{array}$ & $\begin{array}{c}-0.01 \\
(0.010)\end{array}$ \\
\hline Observations & 407 & 407 & 407 & 407 & 407 & 407 \\
\hline R-squared & 0.90 & 0.92 & 0.91 & 0.92 & 0.81 & 0.87 \\
\hline
\end{tabular}

\section{Appendix B: Robustness exercises}

We have rerun our estimations of Model M2 (mortality-adjusted disposable income for the whole population) for an alternative set of parameters of the utility function: $\gamma=0.5$, and $\alpha=0$, which are still consistent with the value of the statistical life provided by Murphy and Topel (2003). Although those parameters may appear to be more "realistic", they lead to unpleasant findings, as the computed willingness to pay appears to be negative at all ages and dates. Put differently, those parameters are associated with a willingness to be paid in exchange for enjoying a long lifespan, which is clearly "unrealistic".

Figures B.1 and B.2 are the counterparts of Figures 4(b) and 7(b), estimated with the new parameters. We see that the profiles are still increasing but are much flatter, which is explained by the fact that the increase in life expectancy translates into a lower adjusted income.

Another robustness check can be provided by using the consumption data (see d'Albis and Badji 2017 for details) rather than disposable income. Figures B.3 and B.4 are the counterparts of Figures 4(a) and 4(b). The slopes of the profiles are steeper than those obtained with income, but the profiles are qualitatively the same. 
Figure B.1:

Log of mortality adjusted disposable income (values relative to cohort 1946) as a function of the date of birth, whole population, for alternative parameters of the utility function

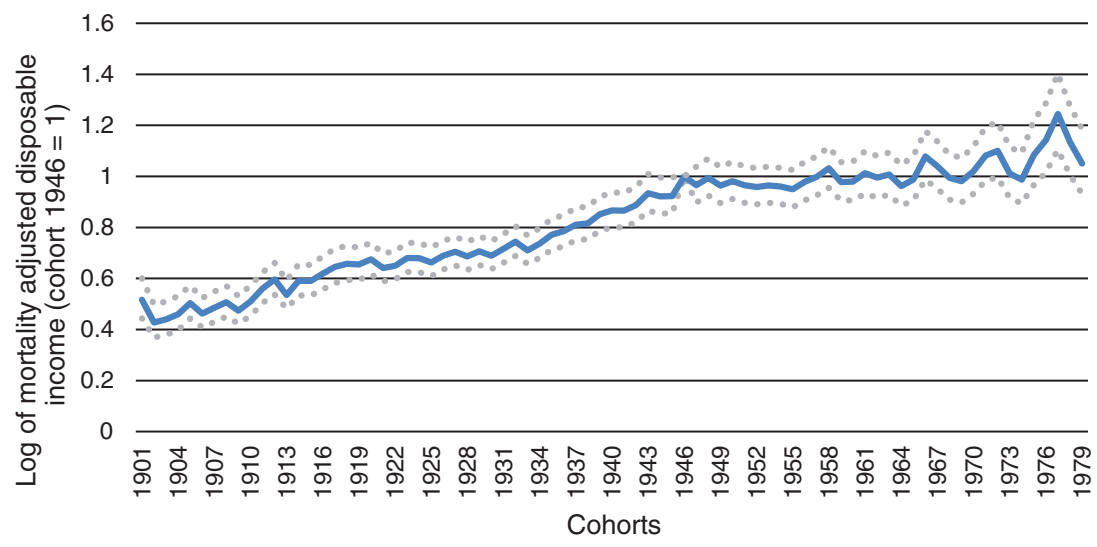

Note: The dotted curves show the confidence intervals at $95 \%$. Model controlled for the age group and the period

\section{Figure B.2:}

Log of mortality adjusted disposable income (values relative to age 47) as a function of the age group, whole population, for alternative parameters of the utility function

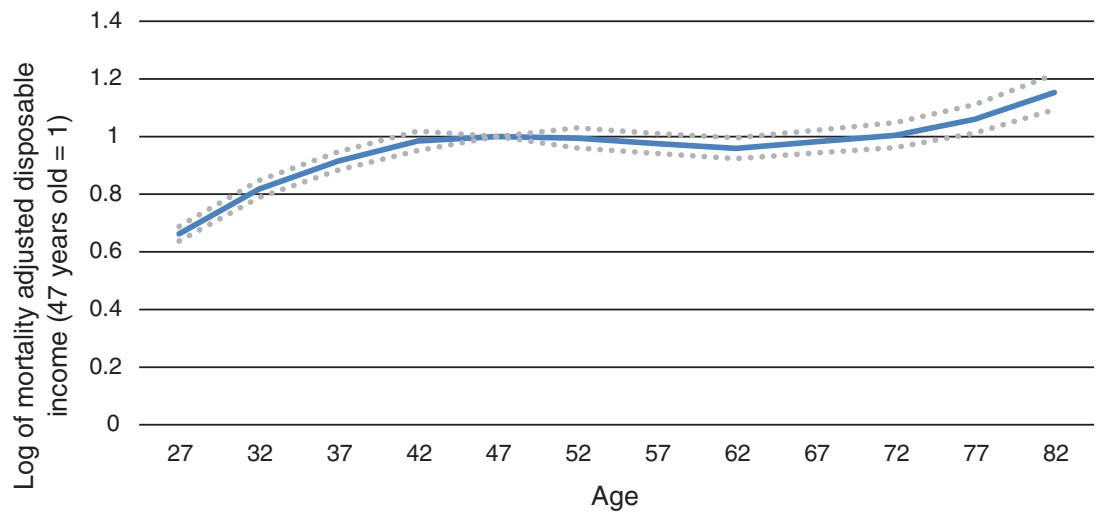

Note: The dotted curves show the confidence intervals at 95\%. Model controlled for the date of birth and the period. 


\section{Figure B.3:}

Log of private consumption (values relative to cohort 1946) as a function of the date of birth, whole population

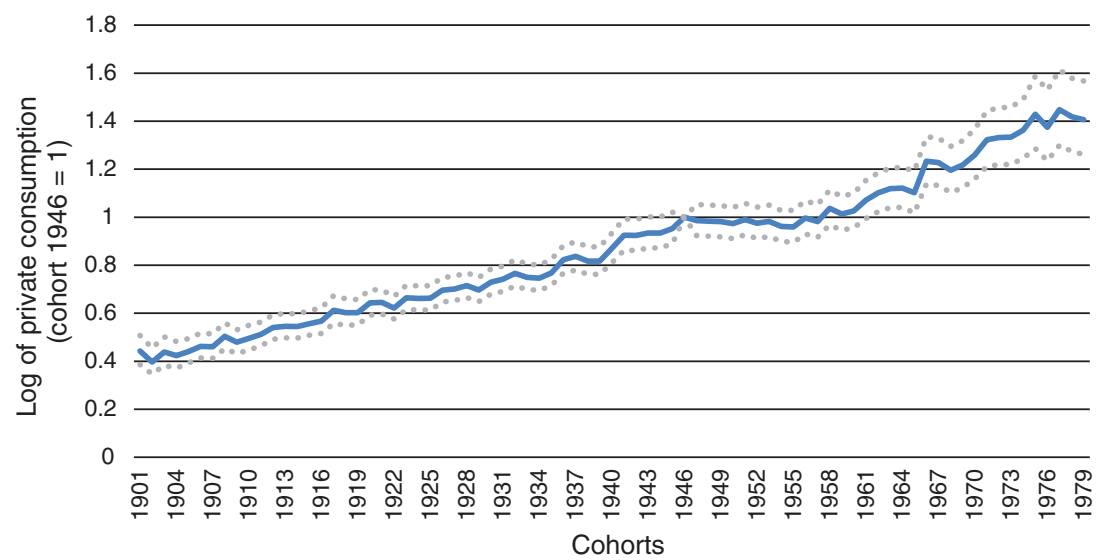

Note: The dotted curves show the confidence intervals at 95\%. Model controlled for the age group and the period.

Figure B.4:

Log of mortality adjusted private consumption (values relative to cohort 1946) as a function of the date of birth, whole population

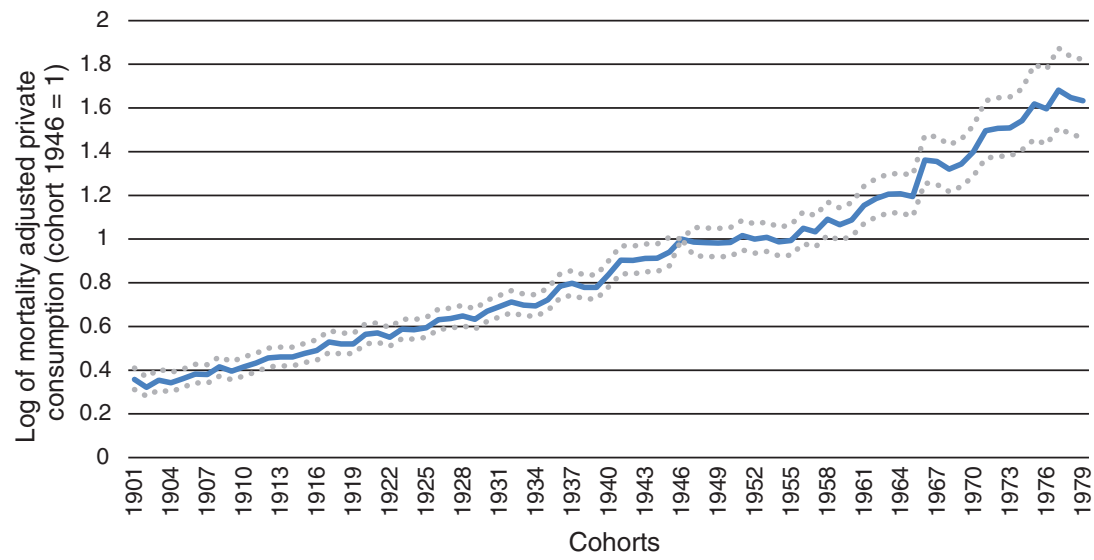

Note: The dotted curves show the confidence intervals at $95 \%$. Model controlled for the age group and the period. 